Article

\title{
Thermo-Structural Evolution of the Val Malenco (Italy) Peridotite: A Petrological, Geochemical and Microstructural Study
}

\author{
Wenlong Liu ${ }^{1,2}$, Yi Cao ${ }^{1}$, Junfeng Zhang ${ }^{1, *}$, Yanfei Zhang ${ }^{3}$, Keqing Zong ${ }^{1}$ and Zhenmin Jin ${ }^{1,2}$ \\ 1 State Key Laboratory of Geological Processes and Mineral Resources, School of Earth Sciences, China \\ University of Geosciences, Wuhan 430074, China; wenlongliu@cug.edu.cn (W.L.); caoyi0701@126.com (Y.C.); \\ kqzong@hotmail.com (K.Z.); zmjin@cug.edu.cn (Z.J.) \\ 2 Institute of Geophysics \& Geomatics, China University of Geosciences, Wuhan 430074, China \\ 3 School of Earth Sciences and Engineering, Hohai University, Nanjing 210098, China; yanfzhang@hhu.edu.cn \\ * Correspondence: jfzhang@cug.edu.cn
}

Received: 9 August 2020; Accepted: 21 October 2020; Published: 28 October 2020

\begin{abstract}
The Val Malenco peridotite massif is one of the largest exposed ultramafic massifs in Alpine orogen. To better constrain its tectonic history, we have performed a comprehensive petro-structural and geochemical study. Our results show that the Val Malenco serpentinized peridotite recorded both pre-Alpine extension and Alpine convergence events. The pre-Alpine extension is recorded by microstructural and geochemical features preserved in clinopyroxene and olivine porphyroblasts, including partial melting and refertilisation, high-temperature $\left(900-1000{ }^{\circ} \mathrm{C}\right)$ deformation and a cooling, and fluid-rock reaction. The following Alpine convergence in a supra-subduction zone setting is documented by subduction-related prograde metamorphism features preserved in the coarse-grained antigorite and olivine grains in the less-strained olivine-rich layers, and later low-temperature $\left(<350{ }^{\circ} \mathrm{C}\right)$ serpentinization in the fine-grained antigorite in the more strained antigorite-rich layers. The strain shadow structure in the more strained antigorite-rich layer composed of dissolving clinopyroxene porphyroblast and the precipitated oriented diopside and olivine suggest dissolution and precipitation creep, while the consistency between the strain shadow structure and alternating less- and more-strained serpentinized domains highlights the increasing role of strain localization induced by the dissolution-precipitation creep with decreasing temperature during exhumation in Alpine convergence events.
\end{abstract}

Keywords: Val Malenco; serpentinized peridotite; tectonic evolution; deformation; strain localization

\section{Introduction}

Recent years have seen a great number of studies on peridotite massifs [1-8], the peridotite shear zone [9-11], and mantle xenoliths [12-16] aiming at exploring the evolution of the lithospheric mantle and mantle wedge. These studies demonstrate intimate relationships between deformation, syn-kinematic P-T conditions, mineralogy, and chemistry in the upper mantle. Compared with shear zones and mantle xenoliths, the large size of the peridotite massif allows an integration of the deformation structures into the mantle lithosphere [17], because microstructures are easily overprinted in the shear zone during emplacement/exhumation, and information is limited for mantle xenoliths given the heterogeneity of lithospheric mantle. In addition, benefiting from its enormous size, multi-stage tectonic history can be constrained or recovered from the field tectonic relationship and heterogeneous deformation in the massif.

Many integrated structural, petrological, and geochemical studies have greatly improved our understanding of the evolutions of peridotite massifs and their represented upper mantle in the Alps 
(Lanzo massif [18,19], Finero Complex [20,21], Cima di Gagnone Massif [7,22]). These peridotite massifs have preserved relics of an earlier tectono-metamorphic evolution related to Jurassic rifting, continental breakup, and development within the Piemonte-Ligurian Ocean which represents part of the Mesozoic Tethys now occurring as ophiolites in the Alps-Apennine orogenic system [23]. However, the tectonic evolution of the Val Malenco ultramafic massif, the largest exposed ultramafic massif in the Alps, is less clear, mainly because of extensive serpentinization in the ocean basin after Jurassic rifting [24] and strong tectono-metamorphic overprinting resulted from the Alpine convergence [25]. Accordingly, previous studies focused on the petrology of the metamorphic events [25-28]. The tectonic evolution of the Val Malenco ultramafic massif is mainly inferred from geochemical studies [29-31], while direct microstructural studies on the peridotite are sparse [3].

Here, we present a comprehensive study on the Val Malenco serpentinized peridotite massif, including microstructural, petrological, and geochemical analyses. The coupled analyses of deformation and metamorphism/metasomatism enabled us to construct an integrated tectonic evolution history of the Val Malenco massif with the emphasis on improving the understanding of deformation processes at a supra-subduction zone setting.

\section{Previous Understanding of Tectonic History of the Val Malenco Unit}

The Val Malenco unit is part of the Central Alpine mountain belt which represents the oceanic lithosphere of Piemonte-Ligurian Tethys, a small oceanic basin separating the Europe plate and the Adria plate, and pieces of the paleo-Europe and paleo-Africa continental thinned margins during the Mesozoic period [23]. It is overlain by the Margna nappe and underlain by the Suretta nappe, which has a pre-Mesozoic basement and a Mesozoic cover, respectively, suggesting a Mesozoic age for the Val Malenco Unit (Figure 1) [29,32]. The main part of the ultramafic peridotite was uplifted from garnet-facies conditions and equilibrated at the spinel-facies conditions [27]. Afterward, lower crustal rocks were welded into the Val Malenco ultramafic rocks (subcontinental mantle) by gabbroic intrusions at $\sim 270 \mathrm{Ma}$ [29]. During the Jurassic rifting, ultramafic rocks were rapidly uplifted by near-isothermal decompression and exposed in the Piemontese ocean basin near the Adriatic margin, experienced extensive low-temperature serpentinization, and developed an Alpine type ophiolite suite [30]. Accompanying the uplifting, melt/fluid infiltration and melt/fluid reaction modified the ancient subcontinental mantle coeval with the incipient opening of oceanic basins $[27,28]$. During the Cretaceous convergence of Alpine metamorphism, the emplaced and serpentinized Val Malenco unit was moderately subducted and experienced pervasive metamorphism which was characterized by metamorphosed serpentinite containing a foliated titanian-clinohumite-bearing magnetite-chlorite-diopside-olivine-antigorite mineral assemblage, indicating greenschist-facies metamorphic conditions $\left(460^{\circ} \mathrm{C}\right.$ and $\left.0.6 \mathrm{GPa}\right)$ in the mantle wedge $[25,33]$. Finally, the exhumation of the massif occurred between $67-73 \mathrm{Ma}$ (the $\mathrm{Ar}^{39}-\mathrm{Ar}^{40}$ ages of amphibole [30,31]) and $32 \mathrm{Ma}$ (the age of the Bergell tonalite intrusion [34]). 


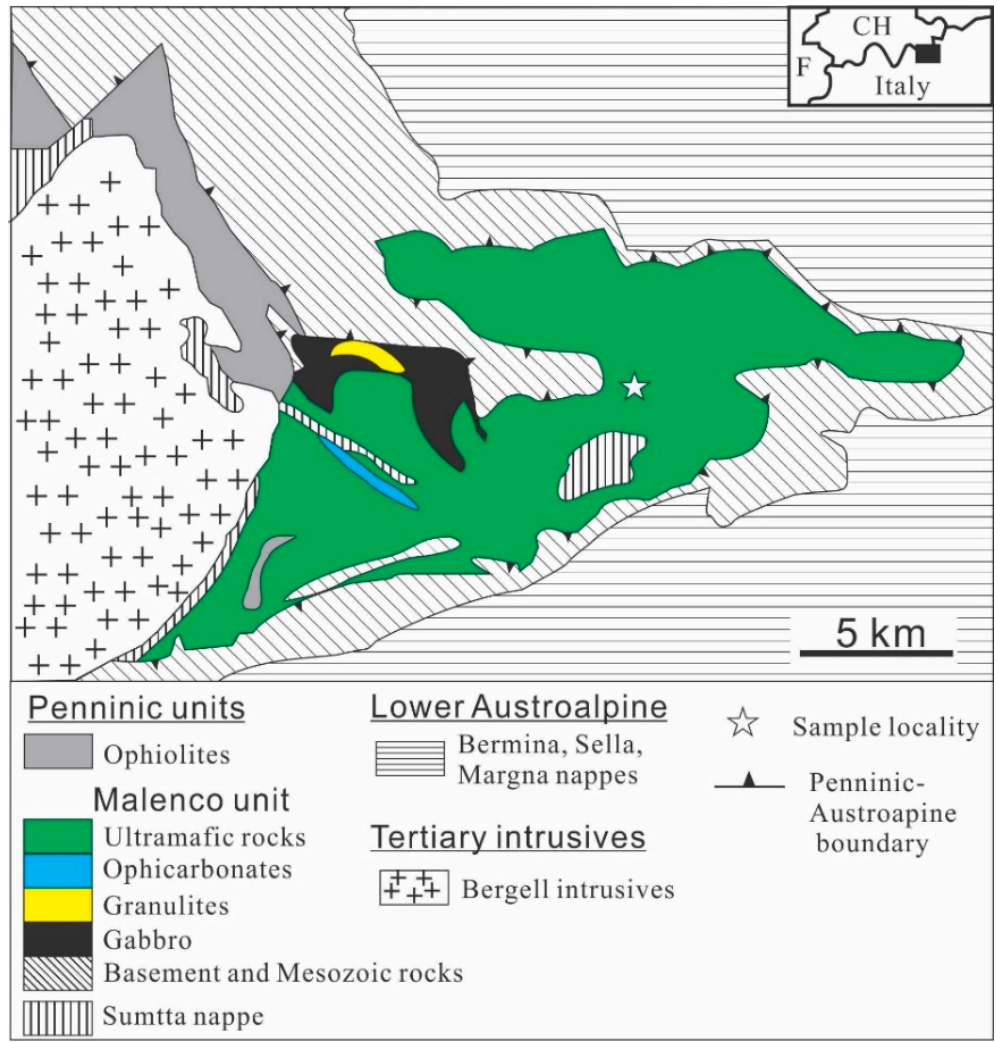

Figure 1. A simplified geological map of the Malenco-Forno unit and sample locality (Franscia, Swiss coordinate: 790.0/129.4). The geological map is modified after Hermann et al. [29]. F: France; $\mathrm{CH}$ : Switzerland.

\section{Methods}

Three serpentinized lherzolite samples were collected from Franscia, Italy (Figure 1). Rock slabs of each sample were cut based on the layering structure and the shape preferred orientations (SPO) of antigorite or olivine before they were doubly polished into $30 \mu \mathrm{m}$ thick thin sections. The thin sections were treated with vibration polishing using $0.05 \mu \mathrm{m}$ colloidal silica for more than $4 \mathrm{~h}$ before analyses.

Major-element analyses of minerals were performed at the Key Laboratory of Submarine Geosciences, State Oceanic Administration, Hangzhou with a JEOL electron microprobe (Superprobe JXA-8100) and at the China University of Geosciences (Wuhan) using a similar JEOL electron microprobe (Superprobe JXA-8230). Both microprobes are equipped with four wavelength-dispersive spectrometers. The analyses were carried out with a $15 \mathrm{kV}$ accelerating voltage, a $5 \mu \mathrm{m}$ width beam with a $20 \mathrm{nA}$ beam current, and a counting time of $30 \mathrm{~s}$ for peaks and $10 \mathrm{~s}$ for backgrounds. All the analytical results were calibrated by natural olivine and diopside standards from the SPI Supplies ${ }^{\circledR}$.

In-situ trace element analyses were performed using laser ablation inductively coupled plasma-mass spectrometry (LA-ICP-MS) at the State Key Laboratory of Geological Processes and Mineral Resources (GPMR) of the China University of Geosciences in Wuhan. The ion signal intensities were measured using an Agilent 7500a ICP-MS equipped with a $193 \mathrm{~nm}$ ArF excimer laser (GeoLas 2005). Helium was used as the carrier gas, and argon was used as the make-up gas. Each analysis included approximately 20-30 s of background acquisition (from a gas blank) and $50 \mathrm{~s}$ of data acquisition from the sample. The element concentrations were calibrated against multiple reference materials (BCR-2G, BIR-1G and BHVO-2G), and a summed metal oxide normalization was applied [35].

The crystallographic preferred orientations (CPOs) and orientation maps were acquired using a Quanta 450 Field Emission Gun (FEG) -scanning electron microscope (SEM) equipped with an HKL Nordlys electron backscattered diffraction (EBSD) detector housed at the GPMR. An accelerating 
voltage of $20 \mathrm{kV}$, a spot size of 6 , and a working distance of $22 \mathrm{~mm}$ were used. The analytical conditions for all measurements have been optimized under a low vacuum condition on non-coated samples to obtain high-quality electron backscattered patterns. The maximum accepted angular deviation for measurements was $1.2^{\circ}$, with average values ranging from 0.73 to $0.88^{\circ}$. Orientation maps were obtained in automatic acquisition mode with a step size of $0.3-6 \mu \mathrm{m}$. The data were then noise-reduced using a "wildspike" correction and a five-neighbor zero solution extrapolation to fill non-indexed pixels based on neighboring pixels using the CHANNEL5s software (Version 4.3) (see Liu et al. [36] for more details).

The active slip systems in plastic deformed crystals could be determined by analyzing grain orientation data (Reference [37] and references therein). In general, two end-member boundaries are commonly used to describe the relationship between dislocations and low-angle boundaries: tilt boundaries and twist boundaries. A tilt boundary is composed of edge dislocations whose crystallographic rotation axes are mutually perpendicular to slip directions and poles of the slip planes. In this case, both the crystallographic rotation axes and the poles of slip planes lie in the tilt boundary. In contrast, a twist boundary is formed by two or more sets of screw dislocations, whose rotation axes and poles to slip planes are perpendicular to the boundary plane.

\section{Petrography}

The serpentinized peridotites are characterized by alternating olivine-rich layers and antigorite-rich layers (Figure 2a). The antigorite-rich layers are composed of fine-grained antigorite $\left(>90 \mathrm{vol} . \%, \operatorname{Atg}^{\mathrm{F}}\right.$ in which the subscript $\mathrm{F}$ refers to fine-grained), olivine (5-10 vol.\%) $\left(\mathrm{Ol}^{\mathrm{F}}\right)$ and minor magnetite (Figure $2 \mathrm{~b}$ ). The olivine-rich layers contain olivine ( $80-85$ vol. \%), clinopyroxene (5-10 vol.\%), antigorite (5-10 vol.\%), and magnetite. Chlorite and titanium clinohumite (Ti-Chu) are also observed in the olivine-rich layers (Figure 2a,c).

In the serpentinized peridotite, olivine can be classified into five types based on grain size and occurrence: porphyroblast $\left(\mathrm{Ol}^{\mathrm{P}}\right)$, coarse-grained $\left(\mathrm{Ol}^{\mathrm{C}}\right)$, and small-grained $\left(\mathrm{Ol}^{\mathrm{S}}\right)$ olivine in the olivine-rich layers, fine-grained olivine $\left(\mathrm{Ol}^{\mathrm{F}}\right)$ in the antigorite-rich layers, and olivine along cracks, the cleavage plane, and grain boundaries $\left(\mathrm{Ol}^{\mathrm{cpx}}\right)$ of clinopyroxene porphyroblasts (Figure $\left.2 \mathrm{~b}-\mathrm{f}\right)$. The $\mathrm{Ol}^{\mathrm{P}}$ grains (0.2-1 $\mathrm{mm}$ in diameter), although rare, can be observed in both antigorite-rich and olivine-rich layers. They often show undulatory extinction (Figure $2 \mathrm{c})$. The $\mathrm{Ol}^{\mathrm{C}}$ grains $(\sim 130 \mu \mathrm{m}$ in diameter) have straight grain boundaries and well-developed triple junctions (Figure 2d). They often intergrow with coarse-grained antigorite, showing a lepidoblastic-granoblastic texture (Figure 2d). The $\mathrm{Ol}^{\mathrm{S}}$ grains ( $\sim 60 \mu \mathrm{m}$ in diameter) have curved grain boundaries. Clinopyroxene and olivine porphyroblasts can be observed in small-grained areas (Figure 2e). However, both $\mathrm{Ol}^{\mathrm{C}}$ and $\mathrm{Ol}^{\mathrm{S}}$ grains are free of undulatory extinction (Figure 2d,e).

Two occurrences of clinopyroxene are observed: porphyroblast $\left(\mathrm{Cpx}^{\mathrm{P}}\right)$ and diopside neoblast (Di). The porphyroblasts, mainly occurring in the serpentine matrix or small-grained area, often show a dusty core of abundant minute magnetite exsolution lamellae and obvious undulatory extinction (Figure $2 \mathrm{~g}, \mathrm{~h}$ ). The $\mathrm{Ol}^{\mathrm{cpx}}$ grains usually surround the $\mathrm{Cpx}^{\mathrm{P}}$ grains as well as filling up the fractures (Figure 2f,h). Diopside neoblasts in the olivine-rich layers or together with the $\mathrm{Cpx}^{\mathrm{P}}$ grains are tabular-shaped euhedral grains free of intracrystalline deformation features. They show clear chemical zonation (Figure $2 \mathrm{i}$ ) with grain sizes of 10 to $100 \mu \mathrm{m}$ (on average $30-40 \mu \mathrm{m}$ ).

Coarse-grained antigorite $\left(\mathrm{Atg}^{\mathrm{C}}\right)$ intergrows with the $\mathrm{Ol}^{\mathrm{C}}$ in the olivine-rich layers. They also have euhedral tabular grain shape and chemical zonation (Figure $2 \mathrm{~d}$ ). In the antigorite-rich layers, fine-grained antigorite $\left(\operatorname{Atg}^{\mathrm{F}}\right)$ (grain size $<50 \mu \mathrm{m}$ ) shows strong SPOs (Figure $2 \mathrm{~b}$ ). 


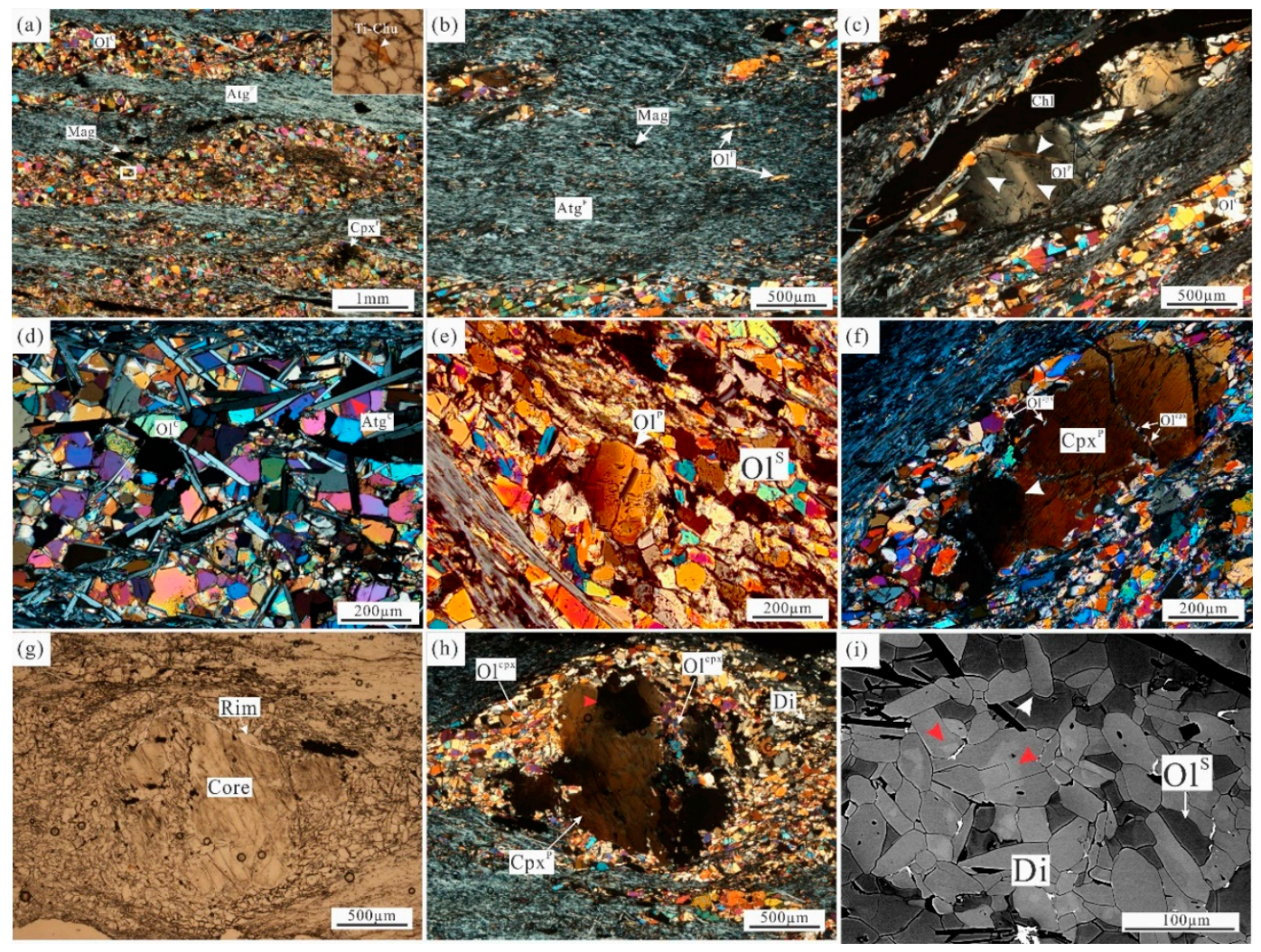

Figure 2. Microstructures of serpentinized peridotite. (a) Serpentinized peridotite composed of alternating antigorite-rich layers and olivine-rich layers. The white box is enlarged at the upper right corner to show the occurrence of clinohumite. (b) An antigorite-rich layer showing elongated fine-grained olivine $\left(\mathrm{Ol}^{\mathrm{F}}\right)$ and antigorite $\left(\mathrm{Atg}^{\mathrm{F}}\right)$. (c) An olivine porphyroblast $\left(\mathrm{Ol}^{\mathrm{P}}\right)$ showing clear undulatory extinction (white arrowheads) and fractures. (d) the lepidoblastic-granoblastic texture in an olivine-rich layer, composed of coarse-grained olivine $\left(\mathrm{Ol}^{\mathrm{C}}\right)$ and antigorite $\left(\mathrm{Atg}^{\mathrm{C}}\right)$. (e) Small-grained olivine $\left(\mathrm{Ol}^{\mathrm{S}}\right)$ with sinuous grain boundaries. (f) Fine-grained olivine surrounding a clinopyroxene porphyroblast and within its fractures $\left(\mathrm{Ol}^{\mathrm{cpx}}\right)$. (g) A clinopyroxene porphyroblast with cloudy core and narrow clean rim. (h) The same clinopyroxene porphyroblast as in (g) showing undulatory extinction and surrounding fine-grained olivine and diopside. (i) Lenticular diopside aggregate in an olivine-rich layer showing an embayment structure (white arrowhead) and growth zonations (red arrowheads). Crossed polarized light images (a-f,h); polarized light image (g); back-scattered electron image (i). Atg: antigorite; Chl: chlorite; Cpx: clinopyroxene; Di: diopside; Mag: Magnetite; Ol: olivine; Ti-Chu: Ti-clinohumite.

\section{Deformation Microstructures}

\subsection{Low-Angle Boundaries and Misorientation Axes of Porphyroblasts}

Because the number of porphyroblasts is too few to measure a meaningful CPO, we used crystallographic orientations of low-angle boundaries and misorientation axes within grains to constrain dislocation slip systems activated in olivine and clinopyroxene porphyroblasts.

The clinopyroxene porphyroblasts display continuous crystallographic orientation gradients and low-angle boundaries (misorientation angles between $2^{\circ}$ and $10^{\circ}$ ) (Figure 3a). The rotation of the crystalline lattice could be as large as $20^{\circ}$ over a distance of $400 \mu \mathrm{m}$. A misorientation profile across a clinopyroxene porphyroblast shows continuous orientation rotation (Figure $3 b$ ). The geometry relationship between the trace of low-angle boundaries and cluster of rotation axes suggests that the slip systems responsible for the formation of low-angle boundaries are the (010)[001] and the (100)[001] (Figure 3c), according to the method described in Reddy et al. [37]. The analyses of many 
clinopyroxene porphyroblasts suggest that the (010)[100] slip system is dominant. Similarly, the olivine porphyroblasts also display continuous crystallographic orientation gradients and well-defined low-angle boundaries (Figure 3d). The low-angle boundaries are commonly subparallel with 15-30 $\mu \mathrm{m}$ spacing. Strong intracrystalline deformation is indicated by orientation distortion of about 20 degrees within the grain (Figure 3e). The misorientation profile across the low-angle boundaries from rim to center shows a progressive change in crystallographic orientation (Figure 3e). The inferred slip systems are the (010)[100], the (021)[100], the (041)[100] and the (001)[100] (Figure 3f). The dominant slip system is the (010)[001] in olivine porphyroblasts.

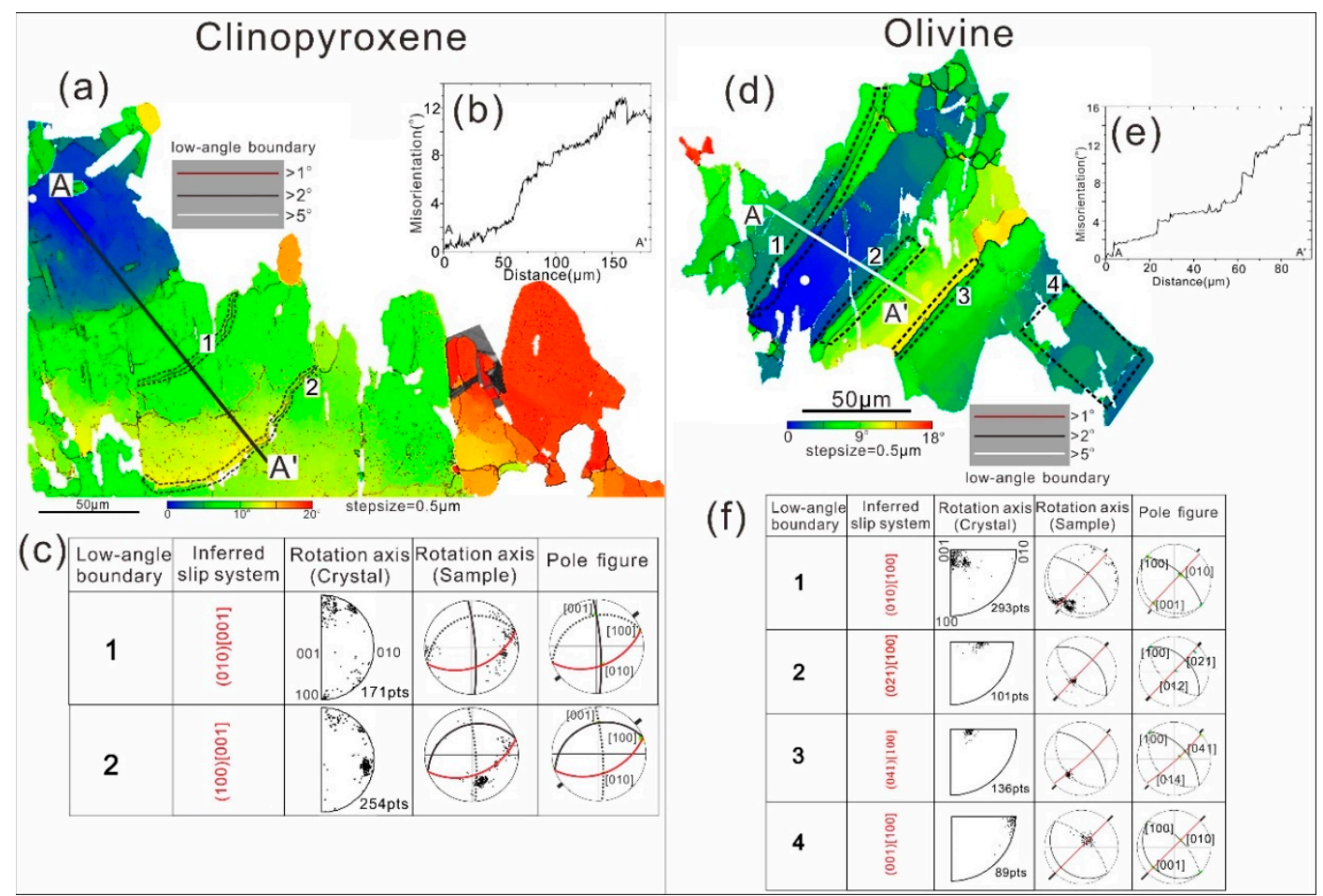

Figure 3. Orientation analyses of clinopyroxene $(\mathbf{a}-\mathbf{c})$ and olivine $(\mathbf{d}-\mathbf{f})$ porphyroblasts. $(\mathbf{a}, \mathbf{d})$ Orientation maps are colored for disorientation angle from a reference point (the white point). Boundaries above $1^{\circ}$ are shown. (b,e) Misorientation profiles along the $\mathrm{AA}^{\prime}$ lines in $(\mathbf{a}, \mathbf{d})$ respectively, suggesting a continuous intracrystalline deformation. (c,f) Slip system analyses based on the method from Reddy et al. [37]. Subsets of disorientation axes data are from the dotted areas $(\# 1,2)$ in (a) and (\#1-4) in (d). The pole figures are lower-hemisphere equal-area projections in $(\mathbf{c}, \mathbf{f})$. The boundary trace orientation (shown as thick black lines outside the primitive circle), the inferred boundary wall (red lines), and slip plane (dotted lines) have been added assuming a tilt boundary geometry.

\subsection{Topotaxial Orientation Analysis}

The clinopyroxene porphyroblasts have abundant minute lamellae of magnetite. There is a clear topotaxial relationship between clinopyroxene porphyroblast and magnetite lamellae (Figure 4), which is characterized by $(100)_{\mathrm{Cpx}} / /(111)_{\mathrm{Mag},},(010)_{\mathrm{Cpx}} / /[\overline{1} 10]_{\mathrm{Mag}},[001]_{\mathrm{Cpx}} / /[\overline{112}]_{\mathrm{Mag}},[101]_{\mathrm{Cpx}} / /[112]_{\mathrm{Mag}}$, $(\overline{101})_{\mathrm{Cpx}} / /(\overline{11} 1)_{\mathrm{Mag}}$. It is noteworthy that the dispersion of the crystallographic axis of magnetite is consistent with the crystallographic axis dispersion of host clinopyroxene, implying that the exsolution took place after intracrystalline deformation. 


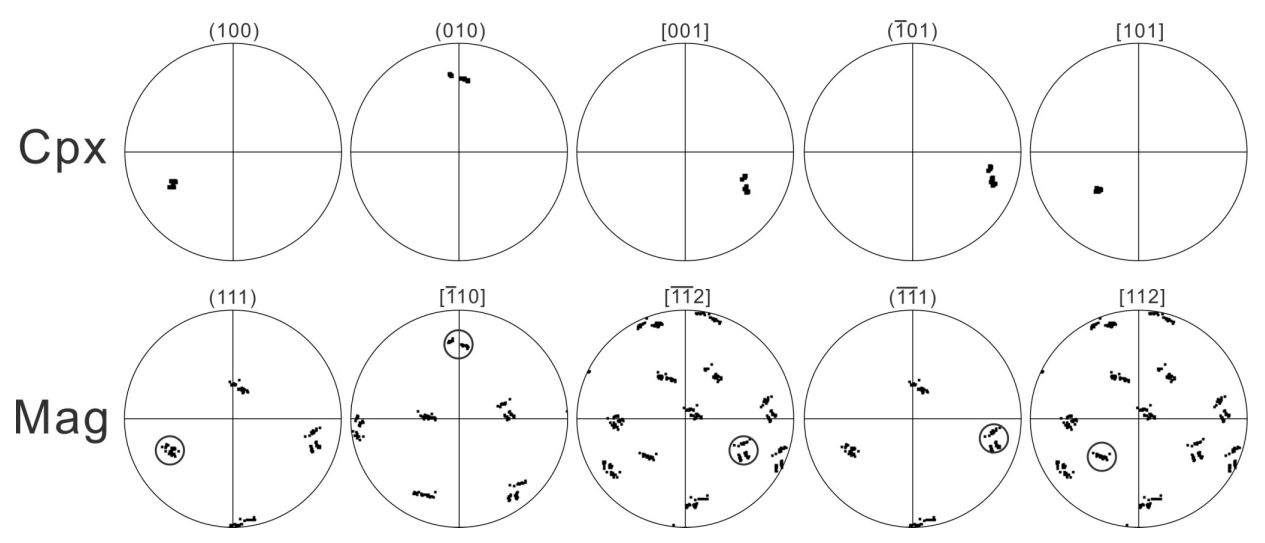

Figure 4. Crystallographic orientations of clinopyroxene porphyroblast and exsolved magnetite. The orientations of magnetite (circled) are consistent with the orientation of the clinopyroxene host. All orientations are presented in the upper hemisphere using a stereographic projection.

\subsection{Pressure Shadow Structure}

The pressure shadow structures of clinopyroxene porphyroblasts are presented in Figure $2 \mathrm{~g}, \mathrm{~h}$ and Figure 5. Figure 5a is a clinopyroxene porphyroblast cut through by olivine veins (Figure 5a). The contact boundary between the olivine vein and the porphyroblast is sinuous. Growth zonation can be observed on both sides of the veins (Figure $5 b$ ). The chemical composition profile across the growth zonation displays abrupt variation in major element contents, characterized by the increase of $\mathrm{Ca}$ content and the decrease of $\mathrm{Al}, \mathrm{Cr}, \mathrm{Na}$, and Fe contents (Figure 5e). Fine-grained diopside aggregates are distributed at the lower left and upper right corners of the porphyroblast, while fine-grained olivine aggregates occur at the lower right and upper left corners (Figure 5a). The diopside grains in fine-grained aggregate have brighter cores of higher Ca contents, while the olivine grains in fine-grained aggregate have grayer cores of higher Mg\# ( 92) (Figure 5c,d).

The orientation map shows that the clinopyroxene porphyroblast is split by olivine veins into three domains containing low-angle boundaries (Figure 6a). Strong intracrystalline deformation is well preserved in clinopyroxene porphyroblast, while the fine-grained diopsides are almost free of intracrystalline deformation, as indicated by the mis2mean misorientation map (Figure 6b). The pole figures of fine-grained diopside aggregate show pronounced CPOs with the [001] and the [100] axes of clinopyroxene clustering at low angles to the lineation and to the foliation normal, respectively (Figure 6c). The orientations of fine-grained diopside are very different from the crystallographic orientation of the clinopyroxene porphyroblast. The orientations of the $[100]_{\mathrm{cpx}}$ and [001] clusters indicate a left lateral shear strain around the clinopyroxene porphyroblast. 

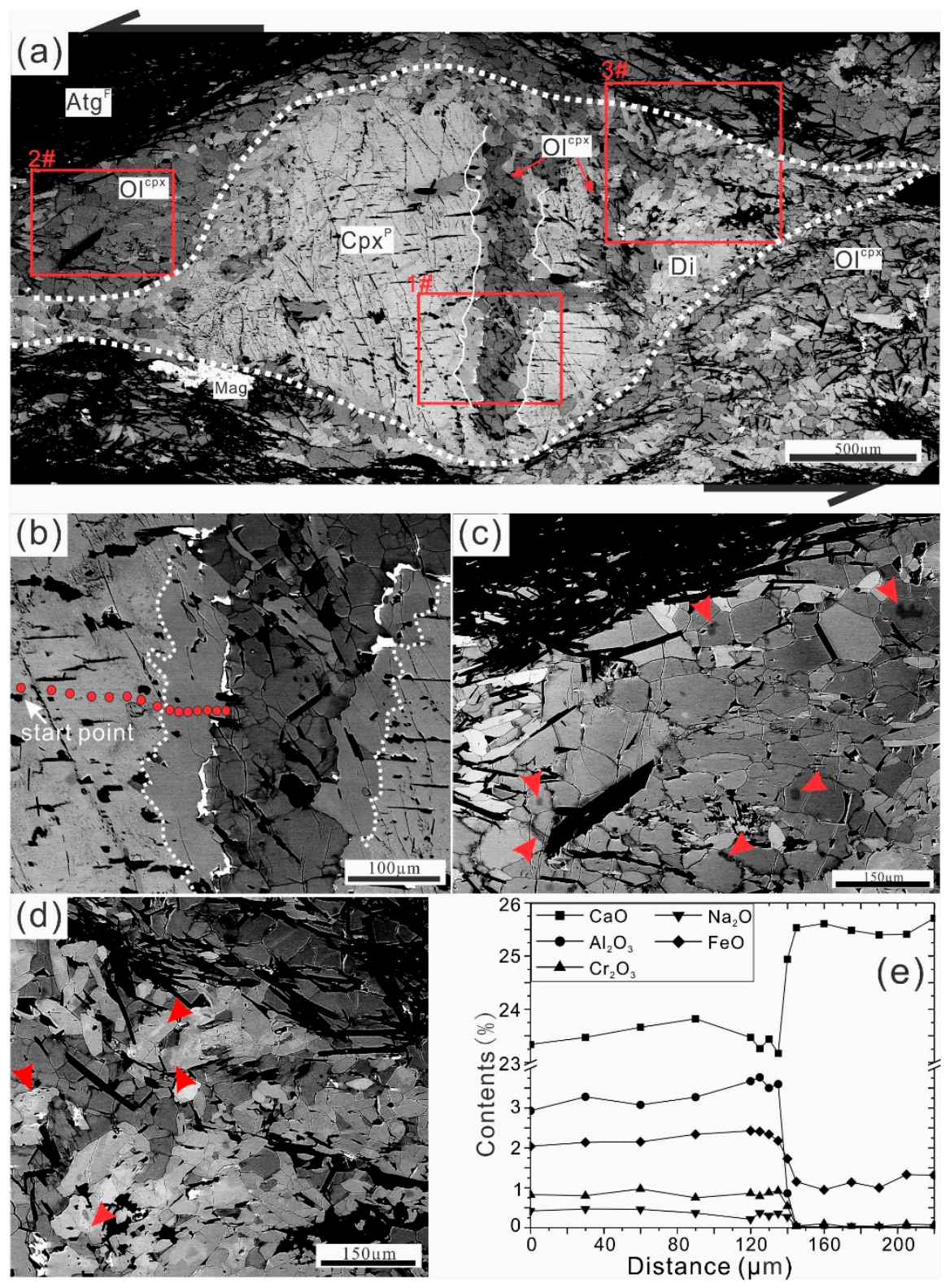

Figure 5. The pressure shadow structure showed by BSE images (a-d) and the major element profile (e). (a) An overview of the pressure shadow structure composed of clinopyroxene porphyroblast, diopside, and olivine. Note the abundance of diopside at the lower-left and upper-right corners, while olivine mainly exists at the lower-right and upper-left corners. The clinopyroxene porphyroblast is dismembered by olivine veins. Red rectangles \#1-3 are enlarged and shown in (b-d). (b) The sinuous contact boundary between the olivine vein and clinopyroxene porphyroblast. The growth zonation is delineated by white dotted curves. The red dots represent the EMPA analytical sites. The corresponding major element profile is shown in (e) (see Table S2 for chemical composition data). (c) The enlarged olivine growth zonation shows olivine grains with a dark core $(\mathrm{Mg \#}=\sim 92)$ (red arrowheads) and bright rim (Mg\# = 86) (see Table S1 for chemical composition data). (d) The enlarged diopside growth zonation shows diopside grains with a bright core and dark rim (red arrowheads) (see Table S2 for chemical composition data). (e) The major element profile along the red dotted line in (b), displaying a sharp change in composition. 

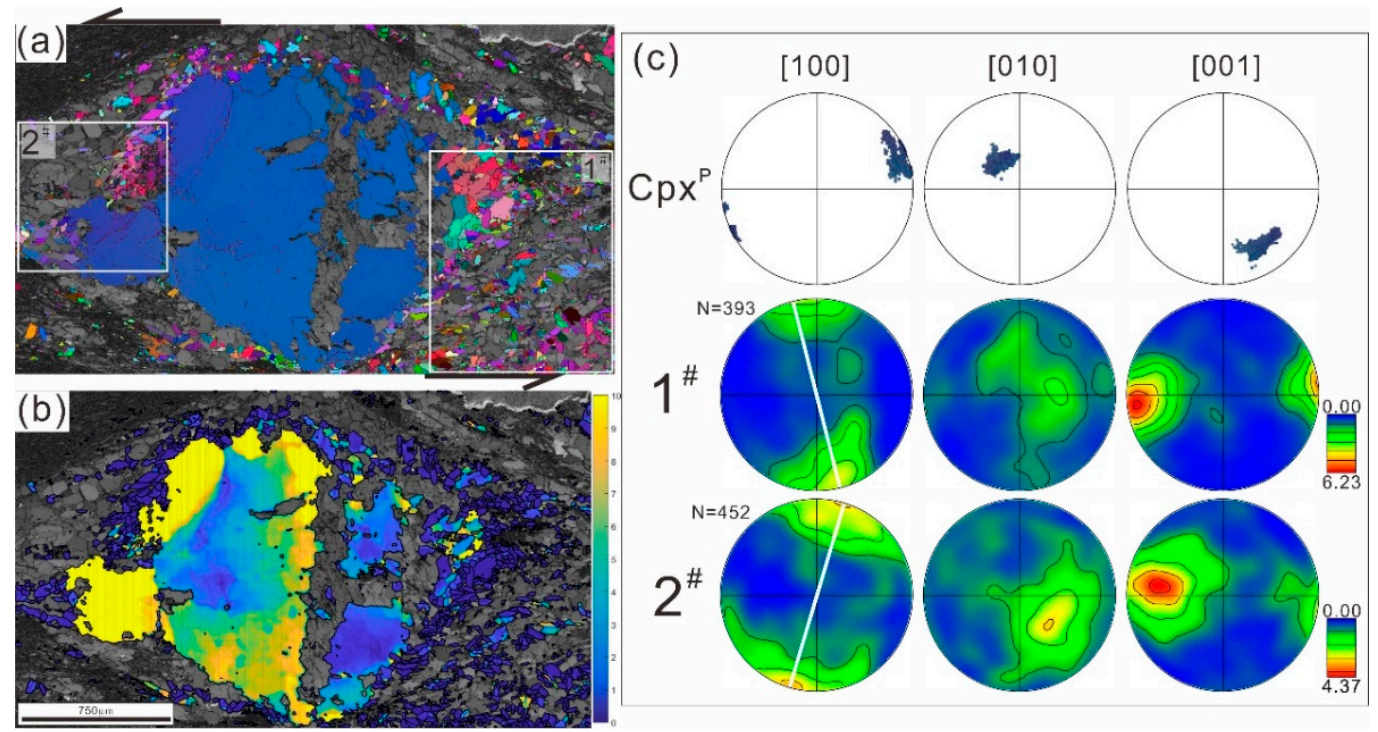

Figure 6. Orientation maps of the clinopyroxene porphyrobalst in Figure 5. (a) A Euler map of clinopyroxene overlaid on a band contrast map. (b) A mis2mean map of clinopyroxene overlaid on a band contrast map. (c) The orientation of the clinopyroxene porphyroblast and pole figures of diopside grains from zone \#1 and \#2 (a). The pole figures are plotted with one point per grain and are presented in the lower hemisphere by using an equal-area projection. A half-width of $20^{\circ}$ and a cluster size of 5 are used. The white solid lines in the pole figures delineate the orientations of the $[100]_{\mathrm{cpx}}$ clusters.

\section{Major and Trace Element Geochemistry in Minerals}

\subsection{Olivine}

Different types of olivine have similar major element compositions ( $\mathrm{Mg \#}=86.2-86.8)$ (Table 1). The $\mathrm{CaO}$ contents are $<0.01$ wt. $\%$ to 0.19 wt. $\%$ in $\mathrm{Ol}^{\mathrm{S}}$ and $\mathrm{Ol}^{\mathrm{Cpx}}$ and negligible in $\mathrm{Ol}^{\mathrm{P}}, \mathrm{Ol}^{\mathrm{C}}$ and $\mathrm{Ol}^{\mathrm{F}}$, respectively. Compared with normal mantle olivine ( $\mathrm{Mg} \#=89-92, \mathrm{NiO}=0.2-0.35 \mathrm{wt} . \%)$ [38], olivine in the Val Malenco serpentinized peridotite has lower Mg\# and higher NiO contents (0.277-0.46 wt.\%) (Figure 7a). 
Table 1. Major element compositions of minerals in Val Malenco serpentinized peridotite.

\begin{tabular}{|c|c|c|c|c|c|c|c|c|c|c|c|c|c|c|c|c|c|c|c|c|c|}
\hline \multirow{3}{*}{$\begin{array}{l}\text { Sample\# } \\
\text { Minerals } \\
\end{array}$} & \multicolumn{5}{|c|}{$\mathrm{V}-2$} & \multicolumn{2}{|c|}{$\mathrm{V}-3$} & \multirow{3}{*}{$\begin{array}{c}\mathrm{V}^{\mathrm{V}} \mathbf{1} \\
\mathrm{C} p \mathrm{x}^{\mathrm{P}} \\
\text { core }\end{array}$} & \multicolumn{4}{|c|}{ V-2 } & \multirow{2}{*}{\multicolumn{2}{|c|}{$\begin{array}{c}\mathrm{V}-3 \\
\mathrm{Cpx}{ }^{\mathrm{P}}\end{array}$}} & \multirow{3}{*}{$\begin{array}{c}\mathrm{V}-4 \\
\mathrm{Cpx}{ }^{\mathrm{P}} \\
\text { core }\end{array}$} & \multirow{3}{*}{$\begin{array}{c}\mathrm{V}-1 \\
\operatorname{Atg}^{\mathrm{F}}\end{array}$} & \multicolumn{3}{|c|}{$\mathrm{V}-2$} & \multirow{2}{*}{\multicolumn{2}{|c|}{$\frac{\mathrm{V}-3}{\operatorname{Atg}^{\mathrm{C}}}$}} \\
\hline & $\mathrm{Ol}^{\mathrm{P}}$ & $\mathrm{Ol}^{\mathrm{C}}$ & $\mathrm{Ol}^{\mathrm{S}}$ & $\mathrm{Ol}^{\mathrm{cpx}}$ & $\mathrm{Ol}^{\mathrm{F}}$ & $\mathrm{Ol}^{\mathrm{C}}$ & $\mathrm{Ol}^{\mathrm{S}}$ & & \multicolumn{2}{|c|}{$\mathrm{Cpx}^{\mathrm{P}}$} & \multicolumn{2}{|c|}{$\mathrm{Di}$} & & & & & \multicolumn{2}{|c|}{ Atg C } & \multirow[t]{2}{*}{$\operatorname{Atg}^{F}$} & & \\
\hline & & & & & & & & & core & rim & core & rim & core & rim & & & core & rim & & core & rim \\
\hline $\mathrm{SiO}_{2}$ & 40.32 & 39.91 & 40 & 40.23 & 40.10 & 40.62 & 40.41 & 52.81 & 53.01 & 54.16 & 53.61 & 55.17 & 52.24 & 54.93 & 51.87 & 43.41 & 41.81 & 42.43 & 42.18 & 41.71 & 43.11 \\
\hline $\mathrm{TiO}_{2}$ & - & 0.01 & 0.02 & 0.01 & - & - & 0.02 & 0.07 & 0.09 & 0.03 & 0.06 & 0.02 & 0.06 & - & 0.12 & - & 0.02 & - & - & 0.03 & 0.01 \\
\hline $\mathrm{Al}_{2} \mathrm{O}_{3}$ & - & 0.02 & 0.01 & 0.01 & 0.02 & - & 0.01 & 3.37 & 2.66 & 0.78 & 1.83 & 0.01 & 3.23 & 0.03 & 2.06 & 1.48 & 2.41 & 1.5 & 1.77 & 2.46 & 0.88 \\
\hline $\mathrm{FeO}$ & 12.95 & 12.67 & 12.75 & 13.16 & 12.69 & 12.7 & 12.87 & 2.29 & 2.01 & 1.63 & 2.15 & 1.20 & 2.20 & 1.08 & 2.08 & 3.62 & 4.02 & 3.13 & 3.53 & 4.39 & 3.04 \\
\hline $\mathrm{MnO}$ & 0.17 & 0.27 & 0.24 & 0.20 & 0.28 & 0.26 & 0.23 & 0.07 & 0.04 & 0.06 & 0.04 & 0.03 & 0.05 & 0.11 & 0.03 & 0.06 & 0.03 & 0.01 & 0.02 & 0.04 & 0.01 \\
\hline $\mathrm{MgO}$ & 46.71 & 46.72 & 46.58 & 45.95 & 46.75 & 46.0 & 46.14 & 16.52 & 17.31 & 17.89 & 17.60 & 17.93 & 16.94 & 17.79 & 18.30 & 38.2 & 37.22 & 39.06 & 37.84 & 36.79 & 39.27 \\
\hline $\mathrm{CaO}$ & 0.01 & 0.01 & 0.08 & 0.05 & 0.01 & - & 0.01 & 23.58 & 23.79 & 25.10 & 23.78 & 25.66 & 23.39 & 25.61 & 23.67 & - & 0.01 & 0.01 & 0.02 & - & 0.01 \\
\hline $\mathrm{Na}_{2} \mathrm{O}$ & 0.01 & - & 0.01 & - & 0.01 & 0.02 & 0.01 & 0.23 & 0.41 & 0.23 & 0.21 & 0.03 & 0.44 & 0.06 & 0.46 & 0.01 & 0.02 & . & 0.01 & - & - \\
\hline $\mathrm{Cr}_{2} \mathrm{O}_{3}$ & 0.02 & & 0.02 & 0.01 & 0.03 & 0.04 & & 0.88 & 0.82 & 0.42 & 0.53 & 0.09 & 0.84 & 0.10 & 0.92 & - & 0.64 & 0.06 & 0.5 & 0.59 & 0.03 \\
\hline $\mathrm{NiO}$ & 0.35 & 0.36 & 0.37 & 0.37 & 0.35 & 0.38 & 0.44 & 0.07 & 0.03 & 0.03 & 0.04 & 0.03 & 0.07 & 0.05 & 0.01 & 0.11 & 0.19 & 0.04 & 0.11 & 0.18 & 0.04 \\
\hline Total & 100.54 & 99.98 & 100.06 & 99.99 & 100.21 & 99.98 & 100.13 & 99.89 & 100.20 & 100.45 & 99.86 & 100.20 & 99.45 & 99.75 & 99.57 & 86.89 & 86.36 & 86.26 & 85.99 & 86.2 & 86.39 \\
\hline Cation/O & 4 & 4 & 4 & 4 & 4 & 4 & 4 & 3 & 3 & 3 & 3 & 3 & 3 & 3 & 3 & 116 & 116 & 116 & 116 & 116 & 116 \\
\hline $\mathrm{Si}$ & 1.00 & 0.99 & 1.00 & 1.00 & 1.00 & 1.01 & 1.01 & 1.92 & 1.92 & 1.96 & 1.95 & 2.00 & 1.91 & 2.00 & 1.88 & 33.68 & 32.86 & 33.15 & 33.17 & 32.89 & 33.57 \\
\hline $\mathrm{Ti}$ & - & - & - & - & - & - & - & - & - & - & - & - & - & - & - & - & 0.01 & - & - & 0.02 & 0.01 \\
\hline $\mathrm{Cr}$ & - & - & - & - & - & - & - & 0.03 & 0.02 & 0.01 & 0.02 & - & 0.02 & - & 0.03 & - & 0.4 & 0.04 & 0.31 & 0.36 & 0.02 \\
\hline $\mathrm{Al}$ & - & - & - & - & - & - & - & 0.14 & 0.11 & 0.03 & 0.08 & - & 0.14 & - & 0.09 & 1.35 & 2.23 & 1.38 & 1.64 & 2.28 & 0.81 \\
\hline $\mathrm{Fe}^{3+}$ & - & 0.01 & 0.01 & - & 0.01 & - & - & - & 0.05 & 0.04 & 0.02 & 0.01 & 0.04 & 0.01 & 0.06 & - & - & - & - & - & - \\
\hline $\mathrm{Fe}^{2+}$ & 0.27 & 0.25 & 0.26 & 0.27 & 0.26 & 0.26 & 0.27 & 0.07 & 0.02 & 0.01 & 0.04 & 0.03 & 0.02 & 0.03 & - & 2.35 & 2.64 & 2.05 & 2.32 & 2.89 & 1.98 \\
\hline $\mathrm{Mn}$ & - & 0.01 & 0.01 & - & 0.01 & 0.01 & & - & & - & - & - & - & - & - & 0.04 & 0.02 & 0.01 & 0.01 & 0.03 & - \\
\hline $\mathrm{Mg}$ & 1.73 & 1.73 & 1.73 & 1.71 & 1.73 & 1.71 & 1.72 & 0.90 & 0.93 & 0.96 & 0.95 & 0.97 & 0.92 & 0.96 & 0.99 & 44.19 & 43.6 & 45.49 & 44.36 & 43.24 & 45.6 \\
\hline $\mathrm{Ca}$ & - & - & - & - & - & - & - & 0.92 & 0.92 & 0.97 & 0.93 & 0.99 & 0.92 & 1.00 & 0.92 & - & 0.01 & 0.01 & 0.01 & - & 0.01 \\
\hline $\mathrm{Na}$ & - & - & - & - & - & - & - & 0.02 & 0.03 & 0.02 & 0.01 & - & 0.03 & - & 0.03 & 0.02 & 0.03 & - & 0.02 & - & - \\
\hline $\mathrm{Ni}$ & - & - & - & - & - & - & - & - & & - & - & - & - & - & - & 0.03 & 0.06 & 0.01 & 0.03 & 0.06 & 0.01 \\
\hline Total & 3.00 & 3.00 & 3.00 & 3.00 & 3.00 & 3.00 & 3.00 & 4.00 & 4.01 & 4.00 & 4.01 & 4.00 & 4.02 & 4.00 & 4.00 & 81.66 & 81.85 & 82.14 & 81.88 & 81.77 & 82.01 \\
\hline Mg\# & 86.5 & 86.8 & 86.7 & 86.2 & 86.8 & 86.6 & 86.5 & 92.8 & 93.9 & 95.2 & 93.6 & 96.4 & 93.2 & 96.7 & 94.0 & 95 & 94 & 96 & 95 & 94 & 96 \\
\hline
\end{tabular}

$\mathrm{Mg \#}=\mathrm{Mg}^{2+} /\left(\mathrm{Mg}^{2+}+\mathrm{Fe}^{2+}\right) \times 100 ;-$ below detection limit. Mineral abbreviations are the same as described in the text. 

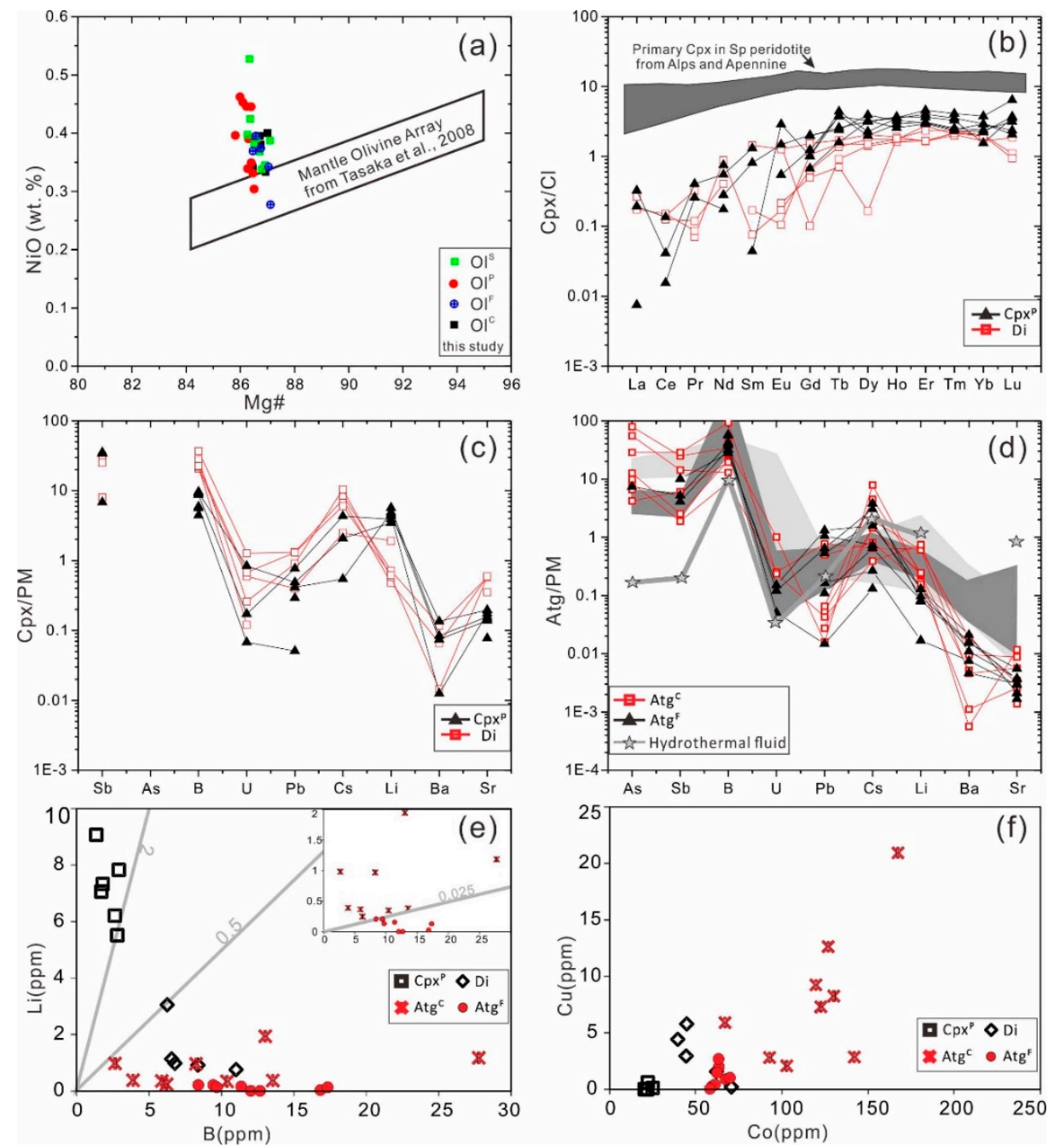

Figure 7. Major and trace element compositions of olivine, clinopyroxene, and antigorite in Val Malenco serpentinized peridotite. (a) $\mathrm{Mg} \#(\mathrm{Mg} /(\mathrm{Mg}+\mathrm{Fe}))$ vs. $\mathrm{NiO}$ (\%) in olivine from Val Malenco (this study). The parallelogram represents the values of $\mathrm{NiO}$ variation with $\mathrm{Mg} \#$ for mantle olivine [11]. (b) REE in clinopyroxene compared to those in clinopyroxene (dark grey zone) of spinel peridotites from the Alps and Apennines [28]. (c) Fluid mobile elements (FMEs) in clinopyroxene. (d) FMEs in antigorite. The FMEs in hydrothermal fluids in the ocean [39] are shown by grey stars. FMEs in antigorite from the subduction channel at relatively high temperatures $\left(350-400{ }^{\circ} \mathrm{C}\right.$ ) (light grey zone) and the mantle wedge at low temperatures $\left(300-350{ }^{\circ} \mathrm{C}\right.$ ) (dark grey zone) [40] are also shown. (e) B and Li contents of clinopyroxene and antigorite. The B vs. Li contents of antigorite are enlarged at the upper-right corner, showing coarse-grained antigorite is enriched in $\mathrm{Li}(\mathrm{Li} / \mathrm{B}>0.025)$. The grey lines represent the ratios of $\mathrm{Li} / \mathrm{B}$. (f) $\mathrm{Cu}$ and Co contents of clinopyroxene and antigorite. All the composition data are included in Tables S1-S4.

\subsection{Clinopyroxene}

The major element compositions of clinopyroxene in the Val Malenco serpentinized peridotite are given in Table 1. The cores of clinopyroxene porphyroblasts $(\mathrm{Mg} \#=92.8-94.0)$ have a diopside composition, containing 2.06-3.37 wt.\% $\mathrm{Al}_{2} \mathrm{O}_{3}, 0.82-0.92$ wt. $\% \mathrm{Cr}_{2} \mathrm{O}_{3}, 0.06-0.12$ wt. $\% \mathrm{TiO}_{2}$ and $0.23-0.46$ wt. $\%$ $\mathrm{Na}_{2} \mathrm{O}$. The diopside neoblasts have higher $\mathrm{Mg} \#$ (93.3-97.0) and lower $\mathrm{TiO}_{2}(<0.01-0.07$ wt.\%), $\mathrm{Al}_{2} \mathrm{O}_{3}\left(<0.01-2.3\right.$ wt.\%), $\mathrm{Cr}_{2} \mathrm{O}_{3}\left(<0.01-0.59\right.$ wt.\%), and $\mathrm{Na}_{2} \mathrm{O}(<0.01-0.37$ wt.\%) contents.

The rare earth element (REE) compositions of clinopyroxene in the Val Malenco serpentinized peridotite are characterized by depleted light rare earth elements (LREE) (Figure 7b). The REE contents are much lower than those of clinopyroxenes in the primary lithospheric mantle [28]. 
The clinopyroxenes show similar patterns of fluid mobile elements (FME), characterized by the enrichment of $\mathrm{Sb}, \mathrm{B}, \mathrm{Cs}$, and Li relative to the primitive mantle (Figure 7c). Compared to diopside neoblasts, clinopyroxene porphyroblasts have higher Li contents and $\mathrm{Li} / \mathrm{B}$ ratios (Figure 7e), and higher $\mathrm{Co}$ and $\mathrm{Cu}$ contents (Figure 7f).

\subsection{Antigorite}

The cores of $\operatorname{Atg}^{\mathrm{C}}$ in the olivine-rich layers have lower $\mathrm{Mg \#}(94)$ and higher $\mathrm{Al}_{2} \mathrm{O}_{3}$ contents (2.41-2.46 wt.\%), compared with the rim and $\mathrm{Atg}^{\mathrm{F}}$ in the antigorite-rich layers (Table 1). The antigorite is enriched in FMEs of As, $\mathrm{Sb}$, and B relative to the primitive mantle (Figure 7d). Compared with $\mathrm{Atg}^{\mathrm{F}}$, $\operatorname{Atg}^{\mathrm{C}}$ have generally higher Li content and $\mathrm{Li} / \mathrm{B}$ ratio (Figure $7 \mathrm{e}$ ), and higher $\mathrm{Cu}$ and Co contents.

\section{Discussion}

\subsection{Thermo-Structural Evolution of the Val Malenco Peridotite}

\subsubsection{Partial Melting and Refertilization}

Previous studies suggest that the protolith of the typical Alpine metamorphic, foliated antigoriteolivine-diopside-chlorite-magnetite \pm Ti-clinohumite ultramafic peridotite, belongs to spinel lherzolite [25], representing the subcontinental mantle $[27,28]$. Differing from primary clinopyroxene in fresh lherzolite $[27,28]$, the clinopyroxene porphyroblasts in serpentinized peridotite show higher Mg\# (92-95) and $\mathrm{Cr}_{2} \mathrm{O}_{3}(0.6-1.1 \mathrm{wt} . \%)$ contents, "N-MORB" REE patterns of flat MREE-HREEs, and depleted LREEs (Figure 7b) [4,41]. Thus, the clinopyroxene porphyroblasts represent relict refractory minerals after the partial melting and metasomatism of mantle rocks during Jurassic rifting. The olivine porphyroblasts have low Mg\# $(86,87)$ and high $\mathrm{NiO}(\sim 0.25-0.47 \mathrm{wt} . \%)$ contents (Figure $7 \mathrm{a})$, which are distinct from the residue origin of partial melting that was deemed to form olivine grains with higher $\mathrm{Mg} \#(>90)[1,11]$. Refertilization is a common process in orogenic lherzolite [4,42] and has been suggested to occur in the Val Malenco ultramafic peridotite during rifting and opening of the Piemonte-Ligurian Ocean during the Jurassic era [27]. Hence, the olivine porphyroblasts are refertilized olivine. The protolith of the Val Malenco serpentinized peridotite may have formed via partial melting of the subcontinental mantle, followed by a refertilization reaction between a refractory harzburgite and ascending basaltic melts [27,29]. The original textures have been erased by later recrystallization and serpentinization (see below).

\subsubsection{High-Temperature Deformation and Followed Cooling}

Both clinopyroxene and olivine prophyroblasts show obvious intracrystalline deformation and well-organized subparallel low-angle boundaries (Figure 3, Figure A1). Based on the methods described in Reddy et al. [37], the inferred dislocation slip systems are (100)[001], (010)[100] and (010)[001] in clinopyroxene porphyroblasts, and [100]\{0k1\}, [100](010), [100](001), [001](010), [001](100) in olivine porphyroblasts, respectively (Figure 3). These observations provide solid evidence for the development of multiple independent slip systems in grains deformed in the dislocation creep regime [43].

The temperature dependence of the dislocation slip system has been suggested based on TEM observations of experimentally deformed diopside and natural samples $[44,45]$. At $800-900{ }^{\circ} \mathrm{C}$, the (100)[001] slip system is the easiest glide system, while the (010)[100], (110)[001] and $\{110\} 1 / 2<110>$ slip systems can also be activated but require a much larger resolved shear stress [44]. Above $1000{ }^{\circ} \mathrm{C}$, the dominant slip systems are $\{110\} 1 / 2<110>,\{110\}[001]$, and (100)[001], corresponding to an increasing critical resolved stress [45]. The observation of the (010)[100] slip system in clinopyroxene porphyroblasts indicates that the clinopyroxene porphyroblasts were deformed by dislocation creep at temperatures lower than $1000^{\circ} \mathrm{C}$

Recent experimental work on olivine deformation has suggested that the deformation of olivine is accommodated by the Peierls mechanism at temperatures $<900{ }^{\circ} \mathrm{C}$, and by the power-law dislocation creep at temperatures $>900^{\circ} \mathrm{C}$, respectively [46,47]. The activation of multiple slip planes, i.e., the $\{0 \mathrm{kl}\}$, 
is favored at a temperature of $\sim 1000{ }^{\circ} \mathrm{C}[48,49]$. The [100] and [001] dislocations are found to be dominant at temperatures above $1200^{\circ} \mathrm{C}$ and below $1000^{\circ} \mathrm{C}$, respectively [50-52]. A transition from [100]-dominated dislocations at $\sim 1100{ }^{\circ} \mathrm{C}$ to [001]-dominated dislocations at $\sim 900{ }^{\circ} \mathrm{C}$ was reported in Durinck et al. [53]. Therefore, the inferred [100]\{0k1\} and [001](010), [001](100) slip systems in olivine porphyroblasts (Figure 3f) indicate a deformation event accommodated by dislocation creep that occurred at $900-1000{ }^{\circ} \mathrm{C}$.

Oriented needles/rods of oxides/silicates in silicate minerals from ultrahigh-pressure (UHP) rocks are indicative of an exsolution or precipitation origin related to cooling [54-56]. Based on the optimization theory of phase boundary, i.e., the temperature of formation is determined by an optimal lattice fit at elevated temperatures estimated from thermal expansion data for the two lattices, the temperature of the magnetite exsolution can be estimated from the angle between different exsolution arrays [56], or crystallographic relationship between magnetite and clinopyroxene [55]. The topotaxial relationship between clinopyroxene porphyroblast and magnetite lamellae, i.e., $(100)_{\mathrm{Cpx}} / /(111)_{\mathrm{Mag}}$, $(010)_{\mathrm{Cpx}} / /[\overline{1} 10]_{\mathrm{Mag}},[001]_{\mathrm{Cpx}} / /[\overline{11} 2]_{\mathrm{Mag},}[101]_{\mathrm{Cpx}} / /[112]_{\text {Mag }}$ and $(\overline{1} 01)_{\mathrm{Cpx}} / /(\overline{11} 1)_{\mathrm{Mag}}$ (Figure 4), is the same as those reported in Feinberg et al. [55], indicating an exsolution temperature of $\sim 860^{\circ} \mathrm{C}[54,55]$.

\subsubsection{Subduction Prograde Metamorphism}

The trace of peridotite serpentinization in the Piemontese oceanic basin was fairly overprinted by the Alpine convergence, during which the Val Malenco ultramafic massif was moderately subducted. The OH-Ti-clinohumite in the olivine-rich layers (Figure 2a) formed by the consumption of serpentine [57] is a product of subduction-related prograde metamorphism. A lepidoblastic-granoblastic texture, well preserved in the olivine-rich layers, is characterized by the intergrowth of euhedral antigorite and olivine (Figure 2d), well-developed triple junctions, free of intracrystalline plastic deformation $[36,58]$ and low dislocation density $\left(1.7 \times 10^{10} \mathrm{~m}^{-2}\right)$ (Figure A1) (see Appendix A.1). Meanwhile, the antigorite-inclusion-rich coarse-grained olivine implies that olivine has grown by consuming antigorite (Figure A2) (see Appendices A.2 and A.3). These observations suggest that the lepidoblastic-granoblastic texture is an equilibrium texture $[23,25]$. The peak metamorphic/equilibrium conditions estimated from $\mathrm{Al}$ content of antigorite [36] and mineral assemblages [26] are $450{ }^{\circ} \mathrm{C}$ and $0.6 \mathrm{GPa}$.

The FMEs of the coarse-grained antigorite also provide evidence for subduction prograde metamorphism. The As, $\mathrm{Sb}$, and $\mathrm{B}$ are 10 to 100 times more enriched in coarse-grained antigorite compared to those of the primitive mantle and hydrothermal fluids in oceans (Figure $7 \mathrm{~d}$ ). On one hand, the signature of over-enrichment of $\mathrm{As}, \mathrm{Sb}$, and $\mathrm{B}$ could be inherited from oceanic serpentinite. Compared with clinopyroxene porphyroblasts, antigorite is depleted in $\mathrm{Li}$ and $\mathrm{Sr}$, and has comparable $\mathrm{Sb}$ and $\mathrm{Pb}$ contents. Hence, the enrichment of $\mathrm{As}$ and $\mathrm{B}$ cannot be inherited from antigorite, especially taking into account the heavy loss of B during the transition from chrysotile/lizardite to antigorite $[59,60]$. On the other hand, the over-enrichment of $\mathrm{As}$ and $\mathrm{Sb}$ is found to be the characteristic of high-grade subducted serpentinites [40,61]. Previous works $[40,61,62]$ on FME mobility have demonstrated that the mobility of some elements, such as As, $\mathrm{Sb}, \mathrm{B}, \mathrm{Cs}$, is associated with low-grade metamorphism $\left(350-400{ }^{\circ} \mathrm{C}\right)$ of metasedimentary rocks which are characterized by high As and $\mathrm{Sb}$ concentrations during subduction [63]. Therefore, the enrichment of As, $\mathrm{Sb}$, and B in coarse-grained antigorite could result from the circulation of the sediment-derived fluids during subduction prograde metamorphism at temperatures around $350-400{ }^{\circ} \mathrm{C}$.

\subsubsection{Later Serpentinization}

In contrast to the lepidoblastic-granoblastic texture preserved in the olivine-rich layer, both $\operatorname{Atg}^{\mathrm{F}}$ and $\mathrm{Ol}^{\mathrm{F}}$ in the antigorite-rich layers developed strong SPO (Figure $2 \mathrm{~b}$ ) and CPOs [36,58], suggesting a syn-kinematic serpentinization process. The temperatures for the later-stage serpentinization are estimated at $300-370{ }^{\circ} \mathrm{C}$ by $\mathrm{Al}$ content in the $\mathrm{Atg}^{\mathrm{F}}$ and the absence of lizardite [36]. 
Compared with $\mathrm{Atg}^{\mathrm{C}}$ in the olivine-rich layers, $\mathrm{Atg}^{\mathrm{F}}$ in the antigorite-rich layers are depleted in almost all the FMEs, while the concentrations of $\mathrm{B}, \mathrm{Pb}$, and $\mathrm{Ba}$ are comparable. As discussed above, because $\mathrm{As}$ and $\mathrm{Sb}$ in $\mathrm{Atg}^{\mathrm{C}}$ are mainly derived from sediment-derived fluid released at temperatures $>350{ }^{\circ} \mathrm{C}[40,62]$, the depletion of $\mathrm{As}$ and $\mathrm{Sb}$ in $\mathrm{Atg}^{\mathrm{F}}$ implies that the serpentinization temperature of $\mathrm{Atg}^{\mathrm{F}}$ in the antigorite-rich layers is lower than $350^{\circ} \mathrm{C}$. The $\mathrm{B} / \mathrm{Li}$ ratio is also an indicator of temperature for hydrous metasomatism because boron is released into fluid much faster at lower temperatures, but lithium can remain in the rocks at higher temperatures $[64,65]$. The higher $\mathrm{B} / \mathrm{Li}$ ratios in $\mathrm{Atg}^{\mathrm{F}}$ than in $\mathrm{Atg}^{\mathrm{C}}$ also agree with a decreasing serpentinization temperature (Figure 7e). A sharp decrease of $\mathrm{Cu}$ and Co concentrations in vent fluids has been reported as temperature drops below $350{ }^{\circ} \mathrm{C}$ [66]. Therefore, the much lower $\mathrm{Cu}$ and Co concentrations in $\mathrm{Atg}^{\mathrm{F}}$ (Figure $7 \mathrm{f}$ ) could be explained by their greatly reduced solubility in fluid due to the decrease of serpentinization temperature below $350{ }^{\circ} \mathrm{C}[66,67]$.

Clinopyroxene porphyroblasts and diopside neoblasts show similar distributions of REE characterized by a slight enrichment of HREEs and depletion of LREEs, while diopside neoblasts have lower REE concentrations (Figure $7 \mathrm{~b}$ ). The high $\mathrm{B} / \mathrm{Li}$ ratios of diopside neoblast are comparable to those of the metamorphic olivine and antigorite but differ from those of the clinopyroxene porphyroblasts with low B/Li ratios (Figure 7e), suggesting a similar metamorphic origin for diopside neoblasts and $\operatorname{Atg}^{\mathrm{F}}$ at lower temperatures during exhumation [64,65]. The low $\mathrm{B} / \mathrm{Li}$ ratios in clinopyroxene porphyroblasts are coherent with high-temperature hydrous metasomatism during emplacement.

\subsection{Deformation during the Exhumation along Subduction Zone Interface}

\subsubsection{Dissolution and Precipitation Creep}

The consistency between strain shadow structure and antigorite foliation (Figure $2 \mathrm{~g}, \mathrm{~h}$ ) and the parallelism of the foliation displayed by alternating antigorite-rich and olivine-rich layers (Figure 2a) indicates a syn-kinematic serpentinization process. Clinopyroxene shows a systematic difference in composition between the diopside neoblasts and clinopyroxene porphyroblasts (Table 1, Figure 5e), indicating an adjustment of the composition to new equilibrium conditions during the development of strain shadow structure. The sinuous boundary between the recrystallized diopside and clinopyroxene porphyroblast (Figure 5b) and the growth of both olivine and diopside in the wing of clinopyroxene porphyroblast (Figure $5 \mathrm{c}, \mathrm{d}$ ) indicate a dissolution and precipitation process [68]. Thus, A syn-kinematic dissolution and precipitation process can be applied to describe the dissolution of clinopyroxene porphyroblast and precipitation of diopside and olivine during serpentinization [69,70].

Clinopyroxene porphyroblasts, acting as rigid objects, could cause local perturbations of the stress field and flow pattern during the syn-kinematic low-temperature serpentinization process [71]. Increasing dissolution may occur adjacent to the porphyroblast on the sides of the shortening site (upper right and lower left corners of the porphyroblast in Figure 5a). Meanwhile, new olivine and diopside may nucleate and grow on the sides of the extensional site (the upper-left and lower-right corners of the porphyroblast in Figure 5a). The dissolution of clinopyroxene porphyroblast and local stress-controlled transportation of cations $(\mathrm{Ca}, \mathrm{Mg}$, $\mathrm{Fe}$ ) have been observed at $\mathrm{mm}$ to $\mathrm{cm}$ scales during the process of serpentinization [69,72]. Local physicochemical gradients can cause precipitation of diopside and olivine. However, the local equilibrium is transient and will evolve during the deformation in a dynamic environment [73], which is evidenced by the growth zonation of both olivine and diopside (Figure 5c,d).

\subsubsection{Role of Strain Localization during Exhumation}

In contrast to the well-developed SPOs and CPOs for both $\mathrm{Atg}^{\mathrm{F}}$ and $\mathrm{Ol}^{\mathrm{F}}$ in the antigorite-rich layers and diopside neoblasts in strain shadow structures, both $\operatorname{Atg}^{\mathrm{C}}$ and $\mathrm{Ol}^{\mathrm{C}}$ in the olivine-rich layers preserve an equilibrium lepidoblastic-granoblastic texture (Figure $2 \mathrm{~d}$ ). $\mathrm{The}^{\mathrm{C}} \mathrm{C}$ displays nearly random fabrics $[36,58]$. This evidence implies most of the strain was accommodated by the antigorite-rich layers with little in the olivine-rich layers. 
It has been suggested that the deformation of olivine in the antigorite-rich layers is accomplished by dissolution creep during serpentinization in our previous study [36]. The pressure-shadow structures indicate also a dissolution and precipitation process (Figures 5 and 6). The viscosity of rocks/minerals deformed by the dissolution-precipitation creep is generally assumed to be lower than the viscosity deformed by dislocation creep, especially at lower temperatures (Reference [74] and references therein). Recent studies have also shown that strain localization can be induced by the dissolution-precipitation creep in ultramafic rocks, especially in the presence of fluid at low temperatures [8,73]. Combined with the temperature decrease from the olivine-rich layers to the antigorite-rich layers, we propose that the differences in microstructure and CPOs of antigorite and olivine from the olivine-rich to the antigorite-rich layers reveal a progressive strain localization coeval with the serpentinization and cooling. Feedback between deformation and permeability probably has resulted in focused fluid flow and the collateral of more effective deformation, thus favoring strain localization and mylonization in the antigorite-rich layers.

Field observations show that dense high-pressure rocks in the subduction zone commonly coexist with a light-weighted and soft antigorite mylonite matrix, suggesting that the buoyant and weak antigorite in the subduction channel can assist with the exhumation of high-pressure rocks [75]. Although the low viscosity of antigorite deformed in the dislocation creep regime is thought to be the main cause [76], antigorite deformed by the dissolution creep is also reported in natural samples [77]. Based on the new results, we suggest that syn-kinematic serpentinization through dissolution-precipitation creep could be an effective mechanism to produce strain localization and exhumation of high-pressure rocks along a subduction interface.

\section{Conclusions}

The Val Malenco serpentinized peridotite provides constraints to the tectonic evolution and deformation of the mantle wedge corner. Our results show that the serpentinized peridotite has recorded a multi-stage thermo-structural history (Figure 8):

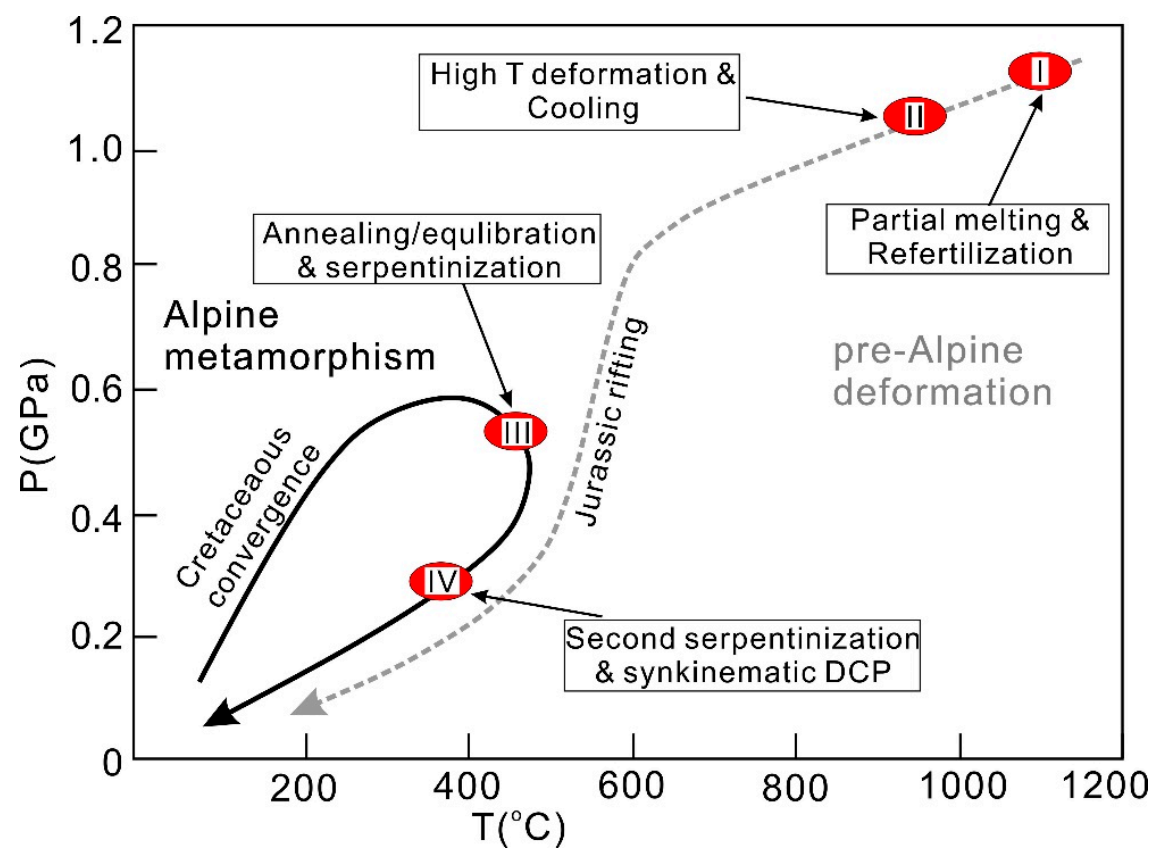

Figure 8. The pressure-temperature paths for the Val Malenco mantle based on previous studies [23,29] and this study. The pre-oceanic exhumation path of the Val Malenco mantle is shown by the grey dotted curve, while the Alpine subduction cycle is shown by the solid curve. The red shaded zones represent different thermo-mechanical stages. 
(1) Partial melting, refertilization, and associated high-temperature deformation took place during the Pre-Alpine extension. The clinopyroxene porphyroblasts have high Mg\# (92-95) and $\mathrm{Cr}_{2} \mathrm{O}_{3}(0.6-1.1 \mathrm{wt} . \%)$ contents, relatively low REE contents, depleted LREE, and a flat MREE-HREE pattern. The olivine porphyroblasts show low Mg\# (86-87) and high NiO content (0.3-0.46 wt.\%). These geochemical features imply that the partial melting of the subcontinental mantle and following refertilization occurred locally, possibly related to the rifting and opening of the Piemonte-Ligurian Ocean during the Jurassic era. Both clinopyroxene and olivine porphyroblasts developed nearly parallel low-angle boundaries. The (100)[001], (010)[100] and (010)[001] slip systems are responsible for the development of clinopyroxene low-angle boundaries, while the [100]\{0kl\}, [100](010), [100](001), [001](010), [001](100) slip systems account for the development of olivine low-angle boundaries. All these slip systems are indicative of a high-temperature $\left(900-1000{ }^{\circ} \mathrm{C}\right)$ dislocation creep in olivine and clinopyroxene porphyroblasts during the early stage of rifting.

(2) The following Alpine convergence in a supra-subduction zone setting is documented by subduction prograde metamorphism and low-temperature serpentinization. The subduction prograde metamorphism is represented by the lepidoblastic-granoblastic structure. The enrichment of As, $\mathrm{Sb}$, and $\mathrm{B}$ in coarse-grained antigorite could result from the circulation of the sediment-derived fluids during subduction at temperatures of $350-400{ }^{\circ} \mathrm{C}$. The later serpentinization is responsible for the formation of the antigorite-rich layers with pronounced SPOs and CPOs in antigorite and olivine, revealing a subsequent syn-kinematic serpentinization process. Compared with coarse-grained antigorite, fine-grained antigorite is more depleted in highly fluid mobile elements (e.g., $\mathrm{Sb}$ and As), and has a higher $\mathrm{B} / \mathrm{Li}$ ratio and lower $\mathrm{Cu}$ and $\mathrm{Co}$ concentrations, suggesting a lower serpentinization temperature $\left(<350^{\circ} \mathrm{C}\right)$.

The deformation of the mantle wedge at low temperatures $\left(300-350{ }^{\circ} \mathrm{C}\right)$ is manifested by the concurrent development of antigorite-rich layers and pressure shadow structures. Dissolution-precipitation creep was responsible for the development of pressure shadow structures and antigorite-rich layers. Most of the strain is accommodated by the antigorite-rich layers with strongly aligned antigorite, while little is imposed in the olivine-rich layers with the well-preserved lepidoblastic-granoblastic structure. We suggest that the dissolution-precipitation creep accompanying serpentinization may result in strain localization and exhumation of high-pressure rocks along the subduction interface.

Supplementary Materials: The following are available online at http://www.mdpi.com/2075-163X/10/11/962/s1, Table S1: Major element compositions of olivine, Table S2: Major element compositions of clinopyroxene, Table S3: REE compositions of clinopyroxene, Table S4: REE compositions of antigorite.

Author Contributions: Conceptualization, W.L., J.Z.; methodology and investigation, W.L., Y.C., K.Z., Y.Z.; writing: W.L., J.Z., Y.C.; supervision and project administration, J.Z., Y.Z. and Z.J. All authors have read and agreed to the published version of the manuscript.

Funding: This work was supported by funds from the National Natural Science Foundation of China (Grant No. 41902221, 41425012), the National Programme on Global Change and Air-Sea Interaction (GASI-GEOGE-02), and the MOST Special Fund for the State Key Laboratory of GPMR at CUG-Wuhan.

Acknowledgments: We would like to acknowledge Haijin Xu, Xiang Zhou, Feng Shi, and Tao Luo for their help with discussions of geochemical interpretations and/or LA-ICP-MS analyses. Harry W. Green II and Jöerg Hermann are deeply appreciated for kindly providing some of the studied samples.

Conflicts of Interest: The authors declare no conflict of interest.

\section{Appendix A}

\section{Appendix A.1. Dislocation Structure}

Dislocation microstructures after oxygen decoration of the sample are shown in Figure A1. The dislocations, which are shown as white dots and lines, are distributed heterogeneously among different olivine grains. Low angle boundaries defined by arrays of dislocations are only observed in $\mathrm{Ol}^{\mathrm{P}}$ 
(Figure A1a,b). The dislocation density is low $\left(5.6 \times 10^{10} \mathrm{~m}^{-2}\right)$ between low angle boundaries as most of the free dislocations tend to accumulate into the low angle boundaries (Figure A1b). The dislocation density of $\mathrm{Ol}^{\mathrm{C}}$ is also low $\left(1.7 \times 10^{10} \mathrm{~m}^{-2}\right)$. Most of the $\mathrm{Ol}^{\mathrm{C}}$ are free of dislocations (Figure $\left.\mathrm{A} 1 \mathrm{c}\right)$. $\mathrm{The} \mathrm{Ol}^{\mathrm{S}}$ grains have higher heterogeneously distributed dislocation density $\left(1.7 \times 10^{12} \mathrm{~m}^{-2}\right)$ (Figure A1d). Free dislocations are found in $\mathrm{Ol}^{\mathrm{Cpx}}$ with low dislocation density $\left(1 \times 10^{10} \mathrm{~m}^{-2}\right)$ (Figure A1e). As for $\mathrm{Ol}^{\mathrm{F}}$ in the antigorite-rich layers, some grains are dislocation free, while others have dislocation densities up to $2.2 \times 10^{11} \mathrm{~m}^{-2}$ (Figure A1f).
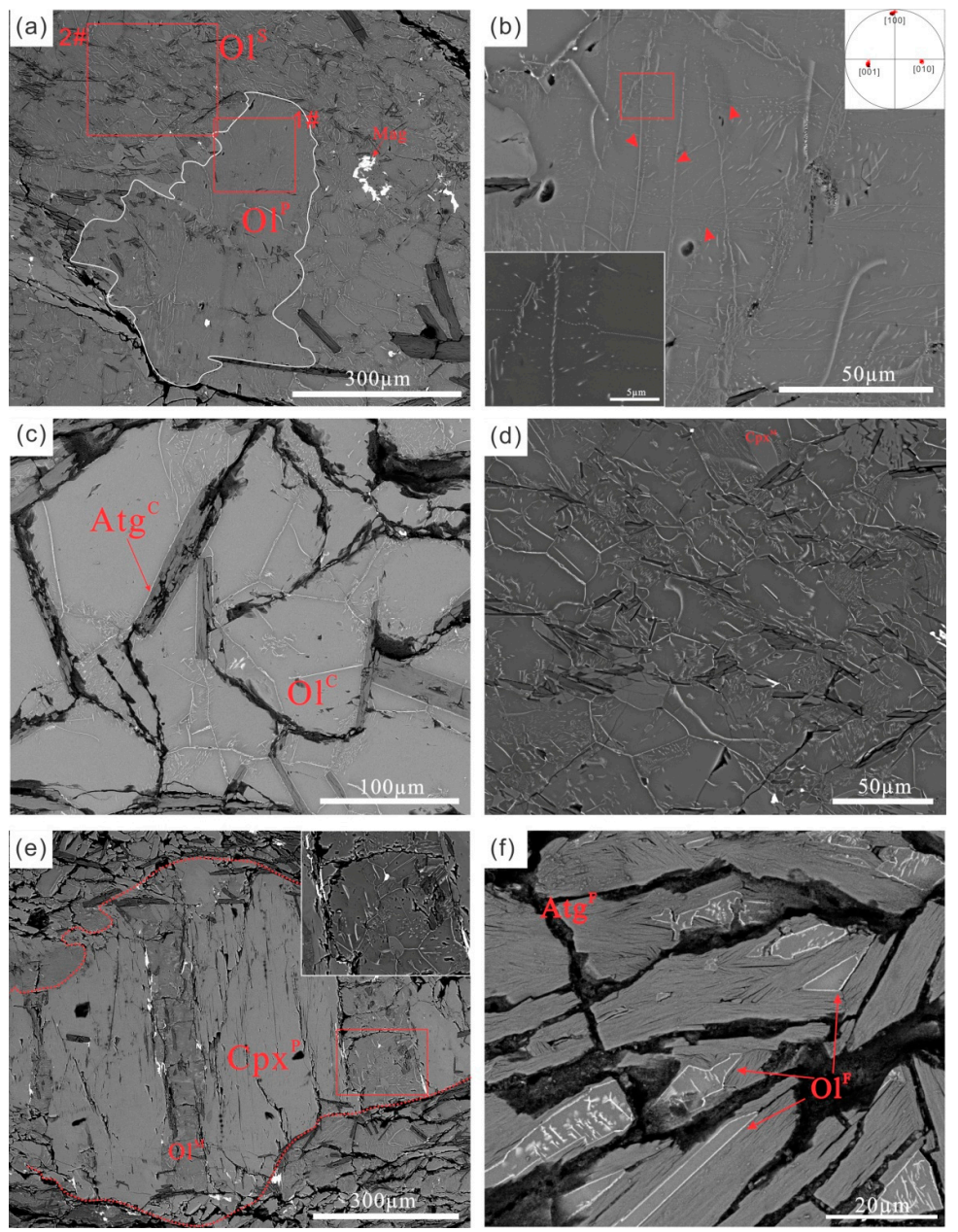

Figure A1. Back-scattered electron (BSE) images showing the dislocation microstructure of different types of olivine after oxygen decoration at $900{ }^{\circ} \mathrm{C}$ for $1 \mathrm{~h}$. The dislocations are shown as white dots and lines. (a) Overview of an olivine porphyroblast and small-grained olivine. Red rectangles \#1 and \#2 are enlarged and shown in (b,d), respectively. (b) An enlarged view of olivine porphyroblast in (a), showing most dislocations are concentrated into low-angle boundaries. The dislocation density is low between boundaries. (c) The dislocation structure of coarse-grained olivine, showing that the cores of olivine grains are almost dislocation free. (d) An enlarged view of small-grained olivine in (a), showing heterogeneous dislocation distribution. (e) The dislocation structure of olivine along clinopyroxene porphyrobalst fractures. (f) The dislocation structure of fine-grained olivine in the antigorite-rich layers.

\section{Appendix A.2. FTIR Measurements}

The water contents and representative FTIR spectra for each mineral are shown in Figure A2. All the spectra are normalized to a thickness of $1 \mathrm{~mm}$. Nearly half of the olivine grains show no detectable $\mathrm{OH}$ absorption bands in the $3000-4000 \mathrm{~cm}^{-1}$ range, while the others show IR absorption 
peaks at wavenumbers ranging from $3668 \mathrm{~cm}^{-1}$ to $3691 \mathrm{~cm}^{-1}$ (Figure A2a), which can be attributed to micro-inclusions of serpentine and/or talc in olivine [78].
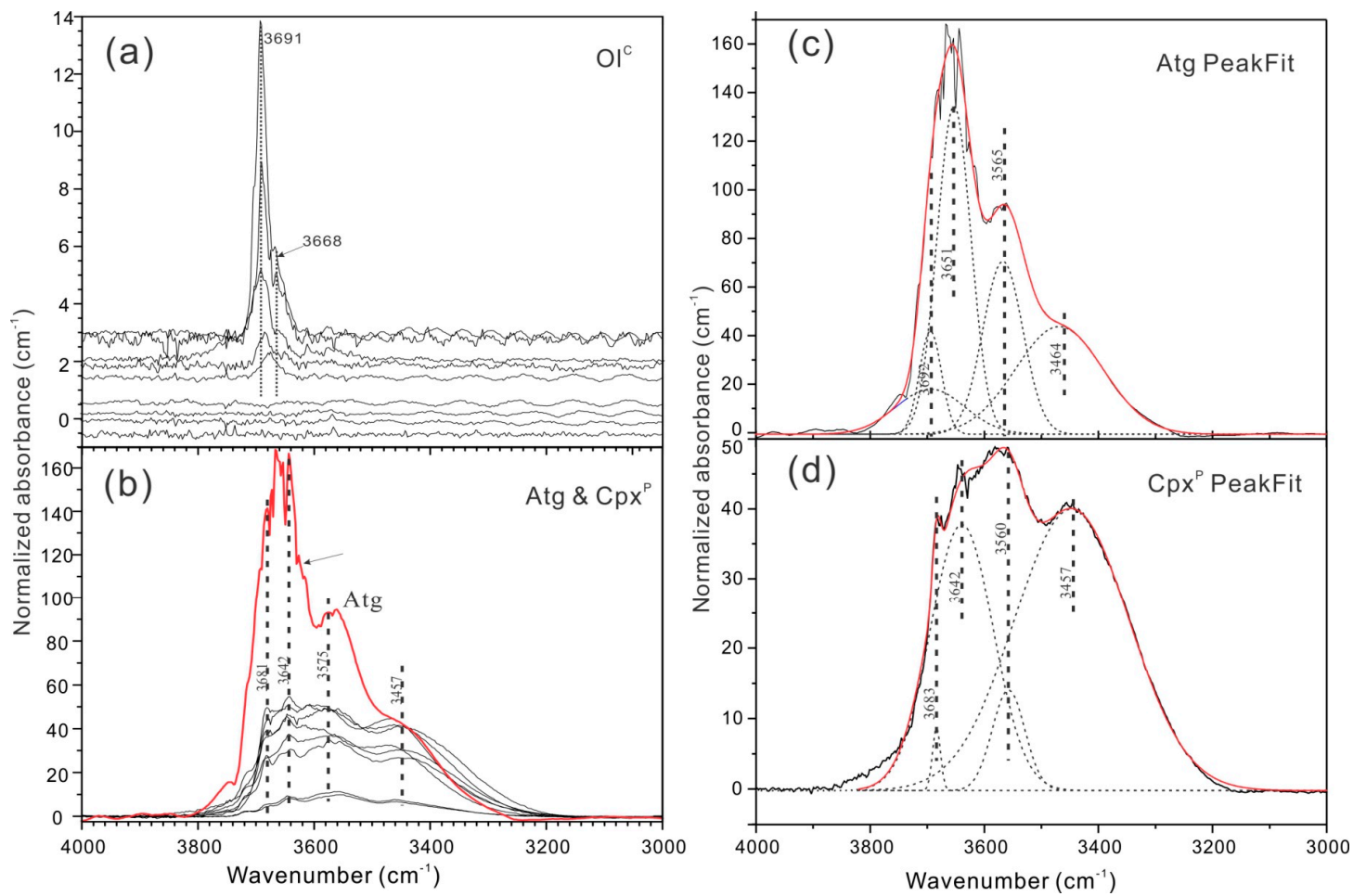

Figure A2. The unpolarized FTIR spectra of coarse-grained olivine and clinopyroxene porphyroblast. (a) The coarse-grained olivine. The observed IR absorption peaks correspond to antigorite IR absorption peaks, as shown in (b,c). (b) Clinopyroxene porphyroblast (black) and antigorite (red). The clinopyroxene spectra are characterized by absorption peaks at 3681, 3642, 3575 and $3457 \mathrm{~cm}^{-1}$, which are all correlated to the absorption peaks of antigorite spectra. (c,d) Atigorte and clinopyroxene porphyroblast spectra analyzed by PeakFit.

Because fractures are well-developed in clinopyroxene porphyroblasts and filled up by antigorite, the PeakFit technique was used to remove the influence of overlapped antigorite IR absorption bands. Both clinopyroxene porphyroblasts and antigorite in the antigorite-rich layers were analyzed (Figure A2b). Peak positions, integrated absorbances, band maxima, and the area-weighted average of band positions were determined by applying a Gaussian distribution function to all component bands [79] (Figure A2c,d). Water contents were calculated by subtracting the integrated absorbances area of antigorite from clinopyroxene at $3457 \mathrm{~cm}^{-1}$. The results represent the minimum water contents in clinopyroxene. The water contents of clinopyroxene porphyroblasts vary between 340 and $600 \mathrm{ppm}$.

The IR absorption spectra of antigorite were collected for comparison. Antigorite shows characteristic IR absorption bands at 3692, 3651, 3565 and $3464 \mathrm{~cm}^{-1}$ (Figure A2b).

\section{Appendix A.3. Discussion}

The subduction prograde metamorphism is also recorded by the inclusions in coarse-grained olivine. The water contents in these olivines can be categorized into two groups: "wet" grains with antigorite inclusions and dry grains (Figure A2a). The antigorite inclusion could be formed through $\mathrm{OH}$ migrating or replacement of the high-pressure hydrous phase inclusion during decompression $[79,80]$, serpentinization along the cracks at low temperature and pressure, and olivine growth at the expense of antigorite. The observed hydrous IR peaks around $3673 \sim 3689 \mathrm{~cm}^{-1}$ (corresponding to serpentine) suggest that deep origin could not be the case because some other IR peaks should also be present $[80,81]$. Although brittle fractures are common in porphyroblasts, they are rare in coarse-grained olivine 
(Figure 2d). Thus, the "wet" olivine grains indicate olivine growth via the consumption of antigorite. The dry coarse-grained olivine may imply that the hydrogen solubility in olivine is negligible at low temperatures, as shown by the hydrogen solubility dependence on temperature [79,82].

\section{References}

1. Cao, Y.; Song, S.; Su, L.; Jung, H.; Niu, Y. Highly refractory peridotites in Songshugou, Qinling orogen: Insights into partial melting and melt/fluid-rock reactions in forearc mantle. Lithos 2016, 252, $234-254$. [CrossRef]

2. Cao, Y.; Jung, H.; Song, S. Seismic anisotropies of the Songshugou peridotites (Qinling orogen, central China) and their seismic implications. Tectonophysics 2018, 722, 432-446. [CrossRef]

3. Jung, H. Deformation fabrics of olivine in Val Malenco peridotite found in Italy and implications for the seismic anisotropy in the upper mantle. Lithos 2009, 109, 341-349. [CrossRef]

4. Le Roux, V.; Bodinier, J.L.; Tommasi, A.; Alard, O.; Dautria, J.M.; Vauchez, A.; Riches, A.J.V. The Lherz spinel lherzolite: Refertilized rather than pristine mantle. Earth Planet. Sci. Lett. 2007, 259, 599-612. [CrossRef]

5. Park, M.; Jung, H. Microstructural evolution of the Yugu peridotites in the Gyeonggi Massif, Korea: Implications for olivine fabric transition in mantle shear zones. Tectonophysics 2017, 709, 55-68. [CrossRef]

6. Rogkala, A.; Petrounias, P.; Tsikouras, B.; Giannakopoulou, P.P.; Hatzipanagiotou, K. Mineralogical Evidence for Partial Melting and Melt-Rock Interaction Processes in the Mantle Peridotites of Edessa Ophiolite (North Greece). Minerals 2019, 9, 120. [CrossRef]

7. Skemer, P.; Katayama, I.; Karato, S.I. Deformation fabrics of the Cima di Gagnone peridotite massif, Central Alps, Switzerland: Evidence of deformation at low temperatures in the presence of water. Contrib. Mineral. Petrol. 2006, 152, 43-51. [CrossRef]

8. Tommasi, A.; Langone, A.; Padrón-Navarta, J.A.; Zanetti, A.; Vauchez, A. Hydrous melts weaken the mantle, crystallization of pargasite and phlogopite does not: Insights from a petrostructural study of the Finero peridotites, southern Alps. Earth Planet. Sci. Lett. 2017, 477, 59-72. [CrossRef]

9. Michibayashi, K.; Oohara, T. Olivine fabric evolution in a hydrated ductile shear zone at the Moho Transition Zone, Oman Ophiolite. Earth Planet. Sci. Lett. 2013, 377, 299-310. [CrossRef]

10. Prigent, C.; Guillot, S.; Agard, P.; Ildefonse, B. Fluid-Assisted Deformation and Strain Localization in the Cooling Mantle Wedge of a Young Subduction Zone (Semail Ophiolite). J. Geophys. Res. Solid Earth 2018, 123, 7529-7549. [CrossRef]

11. Tasaka, M.; Michibayashi, K.; Mainprice, D. B-type olivine fabrics developed in the fore-arc side of the mantle wedge along a subducting slab. Earth Planet. Sci. Lett. 2008, 272, 747-757. [CrossRef]

12. Arai, S.; Ishimaru, S. Insights into petrological characteristics of the lithosphere of mantle wedge beneath arcs through peridotite xenoliths: A review. J. Petrol. 2008, 49, 665-695. [CrossRef]

13. Chin, E.J.; Soustelle, V.; Hirth, G.; Saal, A.E.; Kruckenberg, S.C.; Eiler, J.M. Microstructural and geochemical constraints on the evolution of deep arc lithosphere. Geochem. Geophys. Geosyst. 2016, 17, 2497-2521. [CrossRef]

14. Liu, S.; Tommasi, A.; Vauchez, A.; Mazzucchelli, M. Deformation, annealing, melt-rock interaction, and seismic properties of an old domain of the equatorial Atlantic lithospheric mantle. Tectonic 2019, 38, 1-25. [CrossRef]

15. Payot, B.D.; Arai, S.; Yoshikawa, M.; Tamura, A.; Okuno, M.; Rivera, D.J. Mantle Evolution from Ocean to Arc: The Record in Spinel Peridotite Xenoliths inMt. Pinatubo, Philippines. Minerals 2018, 8, 515. [CrossRef]

16. Tommasi, A.; Vauchez, A.; Ionov, D.A. Deformation, static recrystallization, and reactive melt transport in shallow subcontinental mantle xenoliths (Tok Cenozoic volcanic field, SE Siberia). Earth Planet. Sci. Lett. 2008, 272, 65-77. [CrossRef]

17. Strating, E.H.H.; Rampone, E.; Piccardo, G.B.; Drury, M.R.; Vissers, R.L.M. Subsolidus emplacement of mantle peridotites during incipient oceanic rifting and opening of the mesozoic tethys (voltri massif, NW Italy). J. Petrol. 1993, 34, 901-927. [CrossRef]

18. Kaczmarek, M.A.; Tommasi, A. Anatomy of an extensional shear zone in the mantle, Lanzo massif, Italy. Geochem. Geophys. Geosyst. 2012, 12, 1-24. [CrossRef]

19. Bodinier, J.L.; Godard, M. Orogenic, Ophiolitic, and Abyssal Peridotites. In Treatise on Geochemistry, 2nd ed.; Holland, H.D., Turekian, K.K., Eds.; Elsevier: Amsterdam, The Netherlands, 2014; Volume 3. 
20. Matysiak, A.K.; Trepmann, C.A. The deformation record of olivine in mylonitic peridotites from the Finero Complex, Ivrea Zone: Separate deformation cycles during exhumation. Tectonics 2015, 34, 2514-2533. [CrossRef]

21. Zanetti, A.; Mazzucchelli, M.; Rivalenti, G.; Vannucci, R. The Finero phlogopite-peridotite massif: An example of subduction-related metasomatism. Contrib. Mineral. Petrol. 1999, 134, 107-122. [CrossRef]

22. Scambelluri, M.; Pettke, T.; Cannaò, E. Fluid-related inclusions in Alpine high-pressure peridotite reveal trace element recycling during subduction-zone dehydration of serpentinized mantle (Cima di Gagnone, Swiss Alps). Earth Planet. Sci. Lett. 2015, 429, 45-59. [CrossRef]

23. Trommsdorff, V.; Hermann, J.; Müntener, O.; Pfiffner, M.; Risold, A.C. Geodynamic cycles of subcontinental lithosphere in the Central Alps and the Arami enigma. J. Geodyn. 2000, 30, 77-92. [CrossRef]

24. Puschnig, A.R. Metasomatic alterations at mafic-ultramafic contacts in Valmalenco (Rhetic Alps, N-Italy). Schweiz. Mineral. Petrogr. Mitt. 2002, 82, 515-536.

25. Trommsdorff, V.; Evans, B.W. Alpine metamorphism of peridotitic rocks. Schweiz. Mineral. Petrogr. Mitt. 1974, 54, 333-354.

26. Trommsdorff, V.; Evans, B.W. Progressive metamorphism of antigorite schist in the Bergell tonalite aureole (Italy). Am. J. Sci. 1972, 272, 423-437. [CrossRef]

27. Müntener, O.; Pettke, T.; Desmurs, L.; Meier, M.; Schaltegger, U. Refertilization of mantle peridotite in embryonic ocean basins: Trace element and $\mathrm{Nd}$ isotopic evidence and implications for crust-mantle relationships. Earth Planet. Sci. Lett. 2004, 22, 293-308. [CrossRef]

28. Müntener, O.; Manatschal, G.; Desmurs, L.; Pettke, T. Plagioclase peridotites in ocean-continent transitions: Refertilized mantle domains generated by melt stagnation in the shallow mantle lithosphere. J. Petrol. 2010, 51, 255-294. [CrossRef]

29. Hermann, J.; Müntener, O.; Trommsdorff, V.; Hansmann, W.; Piccardo, B. Fossil crust-to-mantle transition, Val Malenco (Italian Alps). J. Geophys. Res. 1997, 102, 20123-20132. [CrossRef]

30. Müntener, O.; Hermann, J.; Trommsdorff, V. Cooling History and Exhumation of Lower-Crustal Granulite and Upper Mantle (Malenco, Eastern Central Alps). J. Petrol. 2000, 41, 175-200. [CrossRef]

31. Villa, I.M.; Hermann, J.; Müntener, O.; Trommsdorff, V. 39Ar-40Ar dating of multiply zoned amphibole generations (Malenco, Italian Alps). Contrib. Mineral. Petrol. 2000, 140, 363-381. [CrossRef]

32. Peretti, A.; Dubessy, J.; Mullis, J.; Frost, B.R.; Trommsdorff, V. Highly reducing conditions during Alpine metamorphism of the Malenco peridotite (Sondrio, northern Italy) indicated by mineral paragenesis and $\mathrm{H} 2$ in fluid inclusions. Contrib. Mineral. Petrol. 1992, 112, 329-340. [CrossRef]

33. Mellini, M.; Trommsdorff, V.; Compagnoni, R. Antigorite polysomatism: Behaviour during progressive metamorphism. Contrib. Mineral. Petrol. 1987, 97, 147-155. [CrossRef]

34. Von Blackenburg, F. Combined high-precision chronometry and geochemical tracing using accessory minerals: Applied to the Central-Alpine Bergell intrusion (central Europe). Chem. Geol. 1992, 100, 19-40. [CrossRef]

35. Liu, Y.; Hu, Z.; Gao, S.; Günther, D.; Xu, J.; Gao, C.; Chen, H. In situ analysis of major and trace elements of anhydrous minerals by LA-ICP-MS without applying an internal standard. Chem. Geol. 2008, 257, $34-43$. [CrossRef]

36. Liu, W.; Zhang, J.; Barou, F. B-type olivine fabric induced by low temperature dissolution creep during serpentinization and deformation in mantle wedge. Tectonophysics 2018, 722, 1-10. [CrossRef]

37. Reddy, S.M.; Timms, N.E.; Pantleon, W.; Trimby, P. Quantitative characterization of plastic deformation of zircon and geological implications. Contrib. Mineral. Petrol. 2007, 153, 625-645. [CrossRef]

38. De Hoog, J.C.M.; Gall, L.; Cornell, D.H. Trace-element geochemistry of mantle olivine and application to mantle petrogenesis and geothermobarometry. Chem. Geol. 2010, 270, 196-215. [CrossRef]

39. Schmidt, K.; Koschinsky, A.; Garbe-Schönberg, D.; de Carvalho, L.; Seifert, R. Geochemistry of hydrothermal fluids from the ultramafic-hosted Logatchev hydrothermal field, $15^{\circ} \mathrm{N}$ on the Mid-Atlantic Ridge: Temporal and spatial investigation. Chem. Geol. 2007, 242, 1-21. [CrossRef]

40. Deschamps, F.; Godard, M.; Guillot, S.; Chauvel, C.; Andreani, M.; Hattori, K.; Wunder, B.; France, L. Behavior of fluid-mobile elements in serpentines from abyssal to subduction environments: Examples from Cuba and Dominican Republic. Chem. Geol. 2012, 312, 93-117. [CrossRef]

41. McDonough, W.F.; Frey, F.A. Rare earth elements in upper mantle rocks. In Geochemistry and Mineralogy of Rare Earth Elements; Lipin, B.R., McKay, G.A., Eds.; Walter de Gruyter GmbH \& Co KG.: Berlin, Germany, 1989; pp. 99-139. 
42. Varas-Reus, M.; Garrido, C.; Marchesi, C.; Bodinier, J.; Frets, E.; Bosch, D.; Tommasi, A.; Hidas, K.; Targuisti, K. Refertilization Processes in the Subcontinental Lithospheric Mantle: The Record of the Beni Bousera Orogenic Peridotite (Rif Belt, Northern Morocco). J. Petrol. 2016, 57, 2251-2270. [CrossRef]

43. Parks, D.; Ahzi, S. Polycrystalline plastic deformation and texture evolution for crystals lacking five independent slip systems. J. Mech. Phys. Solids 1990, 38, 701-724. [CrossRef]

44. Ingrin, J.; Doukhan, N.; Doukhan, J.-C. Dislocation glide systems in diopside single crystals deformed at 800-900 ${ }^{\circ}$ C. Eur. J. Mineral. 1992, 4, 1291-1302. [CrossRef]

45. Raterron, P.; Doukhan, N.; Jaoul, O.; Doukhan, J.C. High temperature deformation of diopside IV: Predominance of $\{110\}$ glide above $1000^{\circ} \mathrm{C}$. Phys. Earth Planet. Inter. 1994, 82, 209-222. [CrossRef]

46. Demouchy, S.; Schneider, S.E.; Mackwell, S.J.; Zimmerman, M.E.; Kohlstedt, D.L. Experimental deformation of olivine single crystals at lithospheric temperatures. Geophys. Res. Lett. 2009, 36, 1-5. [CrossRef]

47. Long, H.; Weidner, D.J.; Li, L.; Chen, J.; Wang, L. Deformation of olivine at subduction zone conditions determined from in situ measurements with synchrotron radiation. Phys. Earth Planet. Inter. 2011, 186, $23-35$. [CrossRef]

48. Carter, N.L.; Avé Lallemant, H.G. High temperature flow of dunite and peridotite. Geol. Soc. Am. Bull. 1970, 81, 2181-2202. [CrossRef]

49. Durham, W.B.; Goetze, C.; Blake, B. Plastic flow of oriented single crystals of olivine: 2. Observations and interpretations of the dislocation structures. J. Geophys. Res. 1977, 82, 5755-5770. [CrossRef]

50. Bai, Q.; Kohlstedt, D.L. High-temperature creep of olivine single crystals, 2. dislocation structures. Tectonophysics 1992, 206, 1-29. [CrossRef]

51. Goetze, C. The Mechanisms of Creep in Olivine. Philosophical Transactions of the Royal Society A: Mathematical. Phys. Eng. Sci. 1978, 288, 99-119.

52. Katayama, L.; Karato, S.I. Effect of temperature on the B- to C-type olivine fabric transition and implication for flow pattern in subduction zones. Phys. Earth Planet. Inter. 2006, 157, 33-45. [CrossRef]

53. Durinck, J.; Devincre, B.; Kubin, L.; Cordier, P. Modeling the plastic deformation of olivine by dislocation dynamics simulations. Am. Mineral. 2007, 92, 1346-1357. [CrossRef]

54. Hwang, S.L.; Yui, T.F.; Chu, H.T.; Shen, P.; Iizuka, Y.; Yang, H.Y.; Yang, J.S.; Xu, Z. Hematite and magnetite precipitates in olivine from the Sulu peridotite: A result of dehydrogenation-oxidation reaction of mantle olivine? Am. Mineral. 2008, 93, 1051-1060. [CrossRef]

55. Feinberg, J.M.; Wenk, H.R.; Renne, P.R.; Scott, G.R. Epitaxial relationships of clinopyroxene-hosted magnetite determined using electron backscatter diffraction (EBSD) technique. Am. Mineral. 2004, 89, 462-466. [CrossRef]

56. Renne, P.R.; Scott, G.R.; Glen, J.M.G.; Feinberg, J.M. Oriented inclusions of magnetite in clinopyroxene: Source of stable remanent magnetization in gabbros of the Messum Complex, Namibia. Geochem. Geophys. Geosyst. 2002, 3, 1-11. [CrossRef]

57. López Sánchez-Vizcaíno, V.; Trommsdorff, V.; Gómez-Pugnaire, M.T.; Garrido, C.J.; Müntener, O.; Connolly, J.A.D. Petrology of titanian clinohumite and olivine at the high-pressure breakdown of antigorite serpentinite to chlorite harzburgite (Almirez Massif, S. Spain). Contrib. Mineral. Petrol. 2005, 149, 627-646. [CrossRef]

58. Liu, W.; Zhang, J.; Cao, Y.; Jin, Z. Geneses of two contrasting antigorite crystal preferred orientations (CPOs) and their implications for seismic anisotropy in the forearc mantle. J. Geophys. Res. Solid Earth 2020, 125, e2020JB019354. [CrossRef]

59. Kodolányi, J.; Pettke, T.; Spandler, C.; Kamber, B.S.; Ling, K.G. Geochemistry of ocean floor and fore-arc serpentinites: Constraints on the ultramafic input to subduction zones. J. Petrol. 2012, 53, 235-270. [CrossRef]

60. Vils, F.; Müntener, O.; Kalt, A.; Ludwig, T. Implications of the serpentine phase transition on the behaviour of beryllium and lithium-boron of subducted ultramafic rocks. Geochim. Cosmochim. Acta 2011, 75, 1249-1271. [CrossRef]

61. Deschamps, F.; Godard, M.; Guillot, S.; Hattori, K. Geochemistry of subduction zone serpentinites: A review. Lithos 2013, 178, 96-127. [CrossRef]

62. Bebout, G.E.; Bebout, A.E.; Graham, C.M. Cycling of B, Li, and LILE (K, Cs, Rb, Ba, Sr) into subduction zones: SIMS evidence from micas in high-P/T metasedimentary rocks. Chem. Geol. 2007, 239, 284-304. [CrossRef]

63. Jochum, K.P.; Verma, S.P. Extreme enrichment of Sb, $\mathrm{Tl}$ and other trace elements in altered MORB. Chem. Geol. 1996, 130, 289-299. [CrossRef] 
64. Marschall, H.R.; Altherr, R.; Ludwig, T.; Kalt, A.; Gméling, K.; Kasztovszky, Z. Partitioning and budget of Li, Be and B in high-pressure metamorphic rocks. Geochim. Cosmochim. Acta 2006, 70, 4750-4769. [CrossRef]

65. Marschall, H.R.; Altherr, R.; Rüpke, L. Squeezing out the slab-Modelling the release of Li, Be and B during progressive high-pressure metamorphism. Chem. Geol. 2007, 239, 323-335. [CrossRef]

66. Metz, S.; Trefry, J.H. Chemical and mineralogical influences on concentrations of trace metals in hydrothermal fluids. Geochim. Cosmochim. Acta 2000, 64, 2267-2279. [CrossRef]

67. Hannington, M.D.; Jonasson, I.R.; Herzig, P.M.; Petersen, S. Physical and chemical processes of seafloor mineralization at mid-ocean ridges. In Seafloor Hydrothermal Systems: Physical, Chemical, Biological, and Geological Interactions; Humphris, S.E., Zierenberg, R.A., Mullineaux, L.S., Thomson, R.E., Eds.; American Geophysical Union: Washington, DC, USA, 1995; Volume 91, pp. 115-157.

68. Ruiz-Agudo, E.; Putnis, C.V.; Putnis, A. Coupled Dissolution and Precipitation at Mineral—Fluid Interfaces. Chem. Geol. 2014, 383, 132-146. [CrossRef]

69. Austrheim, H.; Prestvik, T. Rodingitization and hydration of the oceanic lithosphere as developed in the Leka ophiolite, north-central Norway. Lithos 2008, 104, 177-198. [CrossRef]

70. Lamadrid, H.M.; Rimstidt, J.D.; Schwarzenbach, E.M.; Klein, F.; Ulrich, S.; Dolocan, A.; Bodnar, R.J. Effect of water activity on rates of serpentinization of olivine. Nat. Commun. 2017, 8, 1-9. [CrossRef]

71. Passchier, C.W.; Trouw, R.A.J. Microtectonics; Springer: Berlin/Heidelberg, Germany, 2005; pp. $159-187$.

72. Iyer, K.; Austrheim, H.; John, T.; Jamtveit, B. Serpentinization of the oceanic lithosphere and some geochemical consequences: Constraints from the Leka Ophiolite Complex, Norway. Chem. Geol. 2008, 249, 66-90. [CrossRef]

73. Hidas, K.; Tommasi, A.; Garrido, C.J.; Padrón-Navarta, J.A.; Mainprice, D.; Vauchez, A.; Barou, F.; Marchesi, C. Fluid-assisted strain localization in peridotites during emplacement of the shallow subcontinental lithospheric mantle. Lithos 2016, 262, 636-650. [CrossRef]

74. Wassmann, S.; Stöckhert, B. Rheology of the plate interface-Dissolution precipitation creep in high pressure metamorphic rocks. Tectonophysics 2013, 608, 1-29. [CrossRef]

75. Guillot, S.; Hattori, K.; Agard, P.; Schwartz, S.; Vidal, O. Exhumation Processes in Oceanic and Continental Subduction Contexts: A Review. In Subduction Zone Geodynamics; Lallemand, S., Funiciello, F., Eds.; Springer: Berlin/Heidelberg, Germany, 2009; pp. 175-204.

76. Hilairet, N.; Reynard, B. Stability and dynamics of serpentinite layer in subduction zone. Tectonophysics 2009, 465, 24-29. [CrossRef]

77. Wassmann, S.; Stöckhert, B.; Trepmann, C.A. Dissolution precipitation creep versus crystalline plasticity in high-pressure metamorphic serpentinites. Geol. Soc. Lond. Spec. Publ. 2011, 360, 129-149. [CrossRef]

78. Beran, A.; Libowitzky, E. Water in natural mantle minerals II: Olivine, garnet and accessory minerals, Water in nominally anhydrous minerals. Rev. Mineral. Geochem. 2006, 62, 169-191. [CrossRef]

79. Litasov, K.D.; Ohtani, E.; Kagi, H.; Jacobsen, S.D.; Ghosh, S. Temperature dependence and mechanism of hydrogen incorporation in olivine at 12.5-14.0 GPa. Geophys. Res. Lett. 2007, 34, 3-7. [CrossRef]

80. Khisina, N.R.; Wirth, R.; Andrut, M.; Ukhanov, A.V. Extrinsic and intrinsic mode of hydrogen occurrence in natural olivines: FTIR and TEM investigation. Phys. Chem. Miner. 2001, 28, 291-301.

81. Koch-Müller, M.; Matsyuk, S.S.; Rhede, D.; Wirth, R.; Khisina, N. Hydroxyl in mantle olivine xenocrysts from the Udachnaya kimberlite pipe. Phys. Chem. Miner. 2006, 33, 276-287. [CrossRef]

82. Bali, E.; Bolfan-Casanova, N.; Koga, K.T. Pressure and temperature dependence of H solubility in forsterite: An implication to water activity in the Earth interior. Earth Planet. Sci. Lett. 2008, 268, 354-363. [CrossRef]

Publisher's Note: MDPI stays neutral with regard to jurisdictional claims in published maps and institutional affiliations.

(C) 2020 by the authors. Licensee MDPI, Basel, Switzerland. This article is an open access article distributed under the terms and conditions of the Creative Commons Attribution (CC BY) license (http://creativecommons.org/licenses/by/4.0/). 